\title{
Possible modification of Alzheimer's disease by statins in midlife: interactions with genetic and non-genetic risk factors
}

\author{
Mitsuru Shinohara ${ }^{1,2+}$, Naoyuki Sato ${ }^{1,2}{ }^{*}$, Munehisa Shimamura ${ }^{3}$, Hitomi Kurinami ${ }^{3}$, \\ Toshimitsu Hamasaki ${ }^{4}$, Amarnath Chatterjee ${ }^{1}$, Hiromi Rakugi ${ }^{2}$ and Ryuichi Morishita ${ }^{1}$ \\ 1 Department of Clinical Gene Therapy, Graduate School of Medicine, Osaka University, Suita, Japan \\ ${ }^{2}$ Department of Geriatric Medicine, Graduate School of Medicine, Osaka University, Suita, Japan \\ ${ }^{3}$ Division of Vascular Medicine and Epigenetics, Department of Child Development, United Graduate School of Child Development, Osaka University Office for \\ University-Industry Collaboration, Suita, Japan \\ ${ }^{4}$ Department of Biomedical Statistics, Graduate School of Medicine, Osaka University, Suita, Japan
}

Edited by:

Alessandro Martorana, University of Rome Tor Vergata, Italy

\section{Reviewed by:}

Alessandro Martorana, University of Rome Tor Vergata, Italy

Mauro Silvestrini, Marche Polytechnic University, Italy

\section{${ }^{*}$ Correspondence:}

Naoyuki Sato, Department of Clinical Gene Therapy, Graduate School of Medicine, Osaka University, 2-2 Yamadaoka, Suita, Osaka 565-0871, Japan

e-mail: nsato@cgt.med.osaka-u.ac.jp

${ }^{\dagger}$ Present address:

Mitsuru Shinohara, Department of Neuroscience, Mayo Clinic,

Jacksonville, FL, USA
The benefits of statins, commonly prescribed for hypercholesterolemia, in treating Alzheimer's disease (AD) have not yet been fully established. A recent randomized clinical trial did not show any therapeutic effects of two statins on cognitive function in $A D$. Interestingly, however, the results of the Rotterdam study, one of the largest prospective cohort studies, showed reduced risk of $A D$ in statin users. Based on the current understanding of statin actions and $A D$ pathogenesis, it is still worth exploring whether statins can prevent $A D$ when administered decades before the onset of $A D$ or from midlife. This review discusses the possible beneficial effects of statins, drawn from previous clinical observations, pathogenic mechanisms, which include $\beta$-amyloid $(A \beta)$ and tau metabolism, genetic and non-genetic risk factors (apolipoprotein $\mathrm{E}$, cholesterol, sex, hypertension, and diabetes), and other clinical features (vascular dysfunction and oxidative and inflammatory stress) of AD. These findings suggest that administration of statins in midlife might prevent $A D$ in late life by modifying genetic and non-genetic risk factors for $A D$. It should be clarified whether statins inhibit $A \beta$ accumulation, tau pathological features, and brain atrophy in humans. To answer this question, a randomized controlled study using amyloid positron emission tomography (PET), tau-PET, and magnetic resonance imaging would be useful. This clinical evaluation could help us to overcome this devastating disease.

Keywords: statin, Alzheimer's disease, prevention, Abeta, isoprenoids

\section{INTRODUCTION}

Alzheimer's disease (AD) is the most common form of dementia. The dramatic increase of life expectancy has resulted in an increasing number of patients with $\mathrm{AD}$, imposing social and economic burden (Alzheimer's Association, 2013). The neuropathological hallmarks of the disease include accumulation of senile plaques, composed of $\beta$-amyloid (A $\beta$ ), and neurofibrillary tangles (NFTs), composed of hyper-phosphorylated tau protein. There is evidence supporting that $\mathrm{A} \beta$ initiates the pathogenesis of $\mathrm{AD}$ (Masters and Beyreuther, 2006; Ballard et al., 2011). However, the failure of clinical trials of "anti- $\mathrm{A} \beta$ " therapies indicates that the intervention should be applied earlier, because $A \beta$ deposition commences decades before the development of clinical symptoms of $\mathrm{AD}$ (Burns, 2009; Jack et al., 2010).

Interestingly, a prospective cohort study suggested that use of hydroxymethylglutaryl coenzyme A (HMG-CoA) reductase inhibitors, or statins, which are widely prescribed for the treatment of hypercholesterolemic patients (Endo, 2008), decreases the incidence of $\mathrm{AD}$ by half. However, controversy exists regarding whether statins have therapeutic effects on $\mathrm{AD}$. In this review, the potential effects of statins against $\mathrm{AD}$ are addressed by drawing upon previous basic and clinical studies. Statin use from midlife could prevent AD.

\section{DYSLIPIDEMIA, AD, AND STATINS}

The first statin, named "compactin," was discovered and isolated from microorganisms by a research team led by Dr. Akira Endo at Sankyo Co. in 1972 (Endo, 2008). His discovery initially suffered from the limitations of animal studies, because rodents were resistant to cholesterol reduction by statins (Endo, 2004). Dozens of studies using larger animals, like chicken, dog, and monkey, and a clinical study in familial hyperlipidemia patients showed that this statin reduces plasma low-density lipoprotein (LDL)-cholesterol level (Mabuchi etal., 1981). Today, several statins are now in clinical use. Statins reduce cholesterol level via the inhibition of HMG-CoA reductase in hepatic cells. Sterol regulatory elementbinding proteins (SREBPs) sense this change in cholesterol level, with a subsequent increase in their LDL receptor (LDLR) expression to uptake serum LDL cholesterol in order to compensate for the reduced cellular cholesterol content (Goldstein and Brown, 2009). Then, clinical studies have shown that statins prevent cardiovascular and cerebrovascular events (Shepherd et al., 1995; 
Crouse etal., 1997; White etal., 2000; Heart Protection Study Collaborative Group, 2002) by reducing plasma cholesterol level (Amarenco and Labreuche, 2009; De Caterina et al., 2010) and regulating an isoprenoid pathway (Downs et al., 1998; Sever et al., 2003; Zhou and Liao, 2010). Of note, the preventative effects could be more evident in middle age (Shepherd et al., 1995, 2002; Heart Protection Study Collaborative Group, 2002).

\section{CLINICAL STUDIES OF STATINS AND AD}

It is conceivable that statins prevent strokes, and thereby reduce the incidence of vascular dementia. However, further studies are required to clarify whether statins are effective to prevent $\mathrm{AD}$. Firstly, two case-control studies supported the preventive effect of statins on AD (Jick et al., 2000; Wolozin et al., 2000), whereas the results of subsequent studies including prospective studies are controversial (Heart Protection Study Collaborative Group, 2002; Shepherd et al., 2002; Zamrini et al., 2004; Dufouil et al., 2005; Rea et al., 2005; Zandi et al., 2005; Sparks et al., 2008; Haag et al., 2009; Feldman et al., 2010; Sano et al., 2011; Bettermann et al., 2012). Two recent randomized clinical studies enrolling around 400 mild-to-moderate $\mathrm{AD}$ patients have failed to show benefits of atorvastatin and simvastatin on cognitive function (Feldman et al., 2010; Sano et al., 2011). Although these two randomized studies could refute the beneficial effects of statins on disease progression in $\mathrm{AD}$ patients, there were several limitations including the duration of intervention (18-month period) and the selection of subjects such as the exclusion of $\mathrm{AD}$ patients requiring treatment for dyslipidemia with lipid-lowering agents. On the other hand, several prospective studies indicate that statins could prevent the onset of AD (Jick et al., 2000; Sparks et al., 2008; Haag et al., 2009; Bettermann et al., 2012). Follow-up period and cohort size of such supportive prospective studies are relatively longer and larger: over 6 years of follow-up and more than 1000 subjects enrolled. A recent meta-analysis by Wong et al. (2013) also showed preventive effects of statins on AD. Of note, several reports indicated preventive effects of statins on $\mathrm{AD}$ only when they included relatively young subjects (Rockwood et al., 2002; Li et al., 2004, 2010a). Taken together, these results of previous clinical studies indicate that the preventive effects and therapeutic effects against AD should be separately considered to elucidate the effects of statins against AD. Such idea corresponds with current understanding of "anti-A $\beta$ " therapies: once clinical symptoms develop, other mechanisms would be required to treat AD (Holmes et al., 2008; Burns, 2009). Therefore, possible benefits of statins against AD might be obtained if administered decades before the onset of the disease.

\section{DIFFERENCES AMONG STATINS}

One important aspect to consider in the effects of statins is their pharmacodynamics and permeability into the brain (Butterfield et al., 2011). Brain-permeable statins, such as simvastatin and lovastatin, might readily act on neurons and glia in the brain, and exert neuroprotective effects including $A \beta$-lowering effects (Fassbender et al., 2001; Simons et al., 2002). However, controversy exists regarding whether brain-permeable statins could be beneficial for AD (Wolozin et al., 2000; Arvanitakis et al., 2008). Among the studies showing preventive effects of statins on $\mathrm{AD}$, only sub-analysis in the Ginkgo Evaluation of Memory Study reported that lipophilic statins tended to reduce the risk of dementia more than did hydrophilic statins (Bettermann et al., 2012). Notably, in the Rotterdam study, which showed a risk reduction of AD by statins, there was no difference in this beneficial effect between hydrophilic and lipophilic statins (Haag et al., 2009). Although the results of these studies may suffer limitations of small numbers for distinguishing hydrophilic and lipophilic statin users, the results of the latter prospective study suggested that the possible preventive effects of statins on $\mathrm{AD}$ might be due to the common mechanism of action of statins rather than the specific mechanism of action of brain-permeable statins. A recent review by Shepardson et al. (2011) discussed the difficulty in attributing the protective effects of statins to specific brain-permeable statins, by pointing out the existence of several confounding effects, including the prescribed dosage, pattern and duration, statistical power, and genetic risks.

\section{NON-GENETIC RISK FACTORS, AD, AND STATINS}

Non-genetic risk factors for $\mathrm{AD}$ include age, gender, physical activity, obesity, midlife hypertension, and diabetes mellitus. Meta-analyses have shown that the odds ratio of women to develop $\mathrm{AD}$ relative to men is 1.56 (95\% CI 1.16-2.10; Jorm and Jolley, 1998). Thus far, no clinical report has recognized the genderspecific beneficial effect of statins on $\mathrm{AD}$. A very high dose of lovastatin of $100 \mathrm{mg} / \mathrm{kg} /$ day, equal to around 100 times the human dose, increased A $\beta$ deposits only in female Tg2576 mice (Park et al., 2003). Compared to men, women receiving statins may lack risk reductions in mortality and stroke (Dale et al., 2007). These preclinical and clinical studies imply that statins may also exert a gender-specific effect on AD.

\section{OBESITY, AD, AND STATINS}

A recent meta-analysis showed that obesity increases the risk of $\mathrm{AD}$ [hazard ratio (HR) 1.80, 95\% CI 1.00-3.29; Beydoun et al., 2008]. Also, it was observed that midlife obesity is associated with an increased risk of some types of cognitive deficit (Debette et al., 2011). Statins might have benefits on obesity by increasing the catabolism of several lipids as well as apolipoprotein B-100, a key player in central obesity (Watts et al., 2003; Ooi et al., 2008). Regulation of peroxisome proliferator-activated receptor- $\alpha$ through an isoprenoid pathway also seems to be important for such benefits of statins (Roglans et al., 2002; Landrier et al., 2004; Paumelle et al., 2006).

\section{HYPERTENSION, AD, AND STATINS}

Several papers report that midlife hypertension is a risk for AD (Skoog et al., 1996; Launer etal., 2000). This is also supported by recent clinical studies showing that blood pressure-lowering therapy can reduce the risk of AD or dementia (Launer et al., 2010; Li et al., 2010b). A meta-analysis of randomized controlled trials showed that statins have beneficial effects on hypertension (Strazzullo et al., 2007). These effects are additive with those of anti-hypertensive drugs, and occur independently of the baseline and change in cholesterol levels. This suggests the involvement of pleiotropic effects against hypertension-induced systemic inflammation and oxidative insults through the regulation of 
an isoprenoid pathway, but not blood pressure lowering itself (Strazzullo et al., 2007). Further analysis of this effect might reveal a role of statins in the crosstalk between midlife hypertension and $\mathrm{AD}$.

\section{DIABETES, AD, AND STATINS}

A recent meta-analysis of 15 prospective cohort studies revealed that diabetes also increases the risk of $\mathrm{AD}$ ( $\mathrm{HR} 1.39,95 \% \mathrm{CI}$ 1.16-1.66; Lu et al., 2009). Interestingly, midlife diabetes seems to accelerate brain aging such as hippocampal atrophy and cognitive decline (Nooyens et al., 2010; Debette et al., 2011). It is well known that statin treatment can reduce the risk of coronary artery disease events in patients with diabetes (Kearney etal., 2008). As the underlying mechanism, regulation of the receptor for advanced glycation end products, RAGE, an important mediator of oxidative and inflammatory processes, might be involved in such statin actions (Lanati et al., 2010; Takeda et al., 2011). Of note, RAGE could also be an important target for AD therapy (Deane, 2012). While a meta-analysis of sub-analysis showed that statins very weakly increase the risk of diabetes itself (HR 1.09, 95\% CI 1.02-1.17; Sattar et al., 2010), J-PREDICT (Japan Prevention Trial of Diabetes by Pitavastatin in Patients with Impaired Glucose Tolerance), an only cohort study whose primary outcome was onset of diabetes, showed a reduction of incidence of diabetes in statin-treated group (Odawara et al., 2013). Therefore, these findings suggest that diabetes may lie as a confounding factor between statins and AD. Further analysis is required to access the effect of stain on the incidence of diabetes, then on that of $\mathrm{AD}$ in pre-diabetic and diabetic patients.

\section{MECHANISMS OF ACTION EFFECTS OF STATINS ON CHOLESTEROL}

Several groups have reported that cholesterol-lowering drugs, besides statins, decrease $A \beta$ production, while cholesterol itself increases $A \beta$ production in cell culture and animal studies (Racchi et al., 1997; Simons et al., 1998; Refolo et al., 2000; Kojro et al., 2001; Shie et al., 2002; Wahrle et al., 2002). Therefore, cholesterollowering could have a possible preventive effect against the onset of $\mathrm{AD}$, though the role of cholesterol in $\mathrm{AD}$ remains unknown in humans. First, it is controversial whether the systemic cholesterol level is relevant to the incidence or the progression of $\mathrm{AD}$ (Jarvik etal., 1995; Yoshitake et al., 1995; Notkola et al., 1998; Romas et al., 1999; Evans et al., 2000; Kivipelto et al., 2002; Tan et al., 2003; Sabbagh et al., 2004). Brain cholesterol or derivative level is also inconsistent among studies using AD brains (Svennerholm and Gottfries, 1994; Sparks, 1997; Mulder et al., 1998; Papassotiropoulos et al., 2002; Schonknecht et al., 2002; Teunissen et al., 2003; Vega et al., 2003; Cutler et al., 2004; Dietschy and Turley, 2004; Kölsch et al., 2004, 2010; Leoni et al., 2006; Vance et al., 2006). One of the aims of these observations is the determination of optimal cholesterol levels for the prevention of AD. Some studies reported that a high systemic cholesterol level or high-density lipoprotein (HDL) cholesterol level is associated with longevity and is also protective against AD development in very elderly people, suggesting different roles of cholesterol at different ages (Weverling-Rijnsburger et al., 1997; Reitz et al., 2010). It is noteworthy that some statins can increase plasma HDL level (Jones et al., 1998). On the other hand, a high midlife serum cholesterol level has been reported to be a risk factor for the incidence of $\mathrm{AD}$ or AD-related pathological changes (Kivipelto et al., 2002; Pappolla et al., 2003). This was confirmed by a recent meta-analysis (Anstey et al., 2008). Therefore, the possible preventive effects of statins on $\mathrm{AD}$ might be related to regulation of cholesterol metabolism in midlife.

One inevitable point that must be considered is that cholesterol itself seems to be very important for brain function and maintenance (Dietschy and Turley, 2004; Vance et al., 2006). In fact, a marked reduction of cholesterol levels by high doses of statins seems to decrease neurotropic support and prove toxic for neurons (Fan et al., 2001; Suzuki et al., 2004). This might correspond with some case reports and prospective studies observing adverse effects of statins, particularly brain-permeable simvastatin and strong cholesterol-lowering atorvastatin, on cognitive function in especially elderly patients with dementia (Wagstaff et al., 2003; Evans and Golomb, 2009; Padala et al., 2012). Following these reports, the U.S. Food and Drug Administration (FDA) recently added safety warnings to statins concerning confusion and memory loss. Such potential adverse effects on cognitive function should be clarified for the appropriate application of statins for $\mathrm{AD}$ prevention or treatment.

ApoE, one of the essential players regulating brain cholesterol metabolism, is the strongest genetic risk factor for AD (Ashford, 2004). The $A P O E-\varepsilon 4$ allele increases the accumulation of senile plaques in $\mathrm{AD}$ patients as well as in cognitively normal people (Reiman et al., 2009; Morris et al., 2010). In the periphery, apoE, mainly secreted from the liver, regulates systemic cholesterol metabolism, and is related to dyslipidemia and arteriosclerosis (Kolovou and Anagnostopoulou, 2007; Kolovou et al., 2008). In APOE- $\varepsilon 4$ carriers, plasma LDL cholesterol levels are around $10 \%$ higher, due to differences in apoE distribution in cholesterol-lipid particles and the metabolism of apoE-containing lipid particles (Cullen et al., 1998; Lucic et al., 2007). Therefore, such increase of plasma cholesterol level in $A P O E-\varepsilon 4$ carriers might be a target for prevention of $\mathrm{AD}$. In the brain, apoE plays important roles in brain function through lipid transport as HDL-like particles (Raber et al., 2000; Ji et al., 2003; Bu, 2009; Filippini et al., 2009; Verghese et al., 2011; Wisdom et al., 2011; Trachtenberg et al., 2012). We showed that statin treatment increased LDLR-related protein 1 (LRP1, one of the apoE receptors)-mediated clearance of $A \beta$ (Shinohara et al., 2010). Interestingly, a prospective study reported that the risk reduction of $\mathrm{AD}$ by statins was observed only in subjects with the APOE-ع4 allele (Li et al., 2004). On the other hand, $A P O E-\varepsilon 4$ carriers seem to be less responsive to statins in the regulation on lipids (Hubacek and Vrablik, 2011). Therefore, these studies might suggest a possible action of statins on amyloid burden through modulation of the apoE-cholesterol pathway.

\section{PLEIOTROPIC EFFECTS OF STATINS \\ Oxidative stress, inflammatory stress, and statins}

Oxidative stress and inflammation are thought to be tightly linked to the pathogenesis and development of AD (Zhu et al., 2007; Pratico, 2008; Bennett et al., 2009; Heneka et al., 2010; Imbimbo 
et al., 2010). More importantly, many epidemiological studies suggest that anti-oxidative drugs and anti-inflammatory drugs may reduce the risk of $\mathrm{AD}$. One randomized clinical trial suggested that anti-oxidative drugs (vitamin $\mathrm{E}$ and selegiline) might slow the progression of AD (Sano et al., 1997). However, a recent randomized clinical trial failed to show any beneficial effect of vitamin $\mathrm{E}$ on the conversion of mild cognitive impairment (MCI) to $\mathrm{AD}$ (Petersen et al., 2005). Controversy also exists among the results of randomized prevention trials of anti-inflammatory drugs (Thal et al., 2005; Lyketsos et al., 2007; Gomez-Isla et al., 2008; Small et al., 2008). A randomized trial even reported an increased risk of $\mathrm{AD}$ using celecoxib and naproxen, a Cox-2 inhibitor, in people aged 70 years or older (Lyketsos et al., 2007). This implies that anti-inflammatory drugs may worsen $\mathrm{AD}$ by reducing some kind of beneficial inflammation for AD (Akiyama and McGeer, 2004; Wyss-Coray, 2006), or, as an elderly community-based cohort study suggested, the increased incidence of $\mathrm{AD}$ in later life in antiinflammatory drug users during midlife may reflect delayed effects of the onset of AD (Breitner et al., 2009). Thus, it remains undetermined whether anti-oxidative or anti-inflammatory drugs are beneficial if administered years before the onset of $\mathrm{AD}$, as with statins.

As noted earlier, several papers showed that an isoprenoiddependent mechanism of statins is involved in their anti-oxidative and anti-inflammatory effects. Reactive oxygen species are attenuated via the regulation of NADPH by statins (Nakagami et al., 2003). Statins can also modulate several inflammatory responses via peroxisome proliferator-activated receptor- $\alpha$ and $-\gamma$ and nuclear factor-kappa B (Liao and Laufs, 2004; Paumelle and Staels, 2007). In an $A D$ animal study, simvastatin reduced oxidative stress and inflammation in amyloid precursor protein (APP) transgenic mice (Tong et al., 2009). It was also shown that fluvastatin reduced oxidative damage and ameliorated neuronal degeneration and cognitive dysfunction in AD model mice (Kurinami et al., 2008). These studies suggest that a possible mechanism of the preventive action of statins against $\mathrm{AD}$ involves anti-oxidative and anti-inflammatory effects via an isoprenoid-dependent pathway.

\section{Effects of statins in vasculature}

Vascular impairment is one aspect of AD. Pathologically impaired vessels have been observed in the brain of $\mathrm{AD}$ patients, as represented by cerebral amyloid angiopathy (CAA). The formation of CAA might be promoted by impairment of vascular flow (Thal et al., 2008; Weller et al., 2009). Furthermore, neurovascular coupling, which controls cerebral blood flow in response to neuronal function, is thought to be involved in the development of $\mathrm{AD}$ (Iadecola, 2004).

Dysfunction of neurovascular coupling can be reversed by antioxidative drugs and anti-inflammatory drugs (Iadecola, 2004). In the Rotterdam study, the HR of $\mathrm{AD}$ was reduced by all statins, regardless of their lipophilicity (Haag et al., 2009). Therefore, the preventive action of statins on $\mathrm{AD}$ could be due to their effects on brain blood vessels, as hydrophilic statins act more dominantly on vessels rather than cells inside the brain. Even a lipophilic statin, simvastatin, improved neurovascular dysfunction in an $\mathrm{AD}$ mouse model, by attenuating oxidative stress and inflammation. Importantly, such reversal of neurovascular dysfunction was associated with improvement of short- and long-term memory (Tong et al., 2009, 2012). An isoprenoid-dependent effect is involved in increasing the endothelial nitric oxide synthase (eNOS) level via the PI3K/Akt pathway, which is important for vascular function and maintenance (Zhou and Liao, 2010). Li et al. (2006) showed that simvastatin increased the levels of Akt, phosphorylated, Akt and eNOS, and reversed learning deficits in Tg2576 mice, independently of $\mathrm{A} \beta$ deposition. Kurata et al. (2012) also reported that atorvastatin and pitavastatin protected against degenerations of neurovascular units and reversed learning deficits in $\operatorname{Tg} 2576$ mice. In addition, regulation of systemic cholesterol by statins might play important roles on prevention of $\mathrm{AD}$ by the reduction of cerebrovascular atherosclerosis, which is reported to correlate with $\mathrm{AD}$ pathology, including senile plaques and CAA (Beach etal., 2007; Yarchoan etal., 2012). These studies suggest that one of the important actions of statins with regards to $\mathrm{AD}$ could involve blood vessels in the brain.

\section{A $\beta$ metabolism and statins}

The Religious Orders Study, a longitudinal clinical pathologic study, observed that statin users, especially those using lipophilic statins, are less likely to have amyloid load in the brain of old Catholic clergy at autopsy (Arvanitakis et al., 2008). Another study also showed that cognitively normal people who used statins have fewer amyloid plaques at autopsy (Li et al., 2007). The mechanism by which statins regulate $A \beta$ metabolism in the brain is still not fully clarified yet. As with other proteins, the level of $\mathrm{A} \beta$ is determined by the balance of its production and clearance. Blood vessels in the brain play an important role in the regulation of A $\beta$ clearance (Bell and Zlokovic, 2009; Weller et al., 2009). Especially, LRP1 could be involved in $A \beta$ clearance by brain blood vessels (Bell and Zlokovic, 2009). Our recent observations showed that fluvastatin increased $A \beta$ clearance from the brain through up-regulating LRP1 level in the brain vessels of wild-type and APP transgenic mice. The notion that statins increase LRP1-mediated A $\beta$ clearance was also supported by an in vitro model of $\mathrm{A} \beta$ clearance, using human brain blood vessel cells. In addition, an isoprenoid-dependent pathway mediates this effect (Shinohara et al., 2010). These results provide evidence that brain vessels may be directly involved in statins' action on $A \beta$ metabolism. Additional studies using conditional LRP1-knockout mice could clarify the involvement of LRP1 in the enhancement of $A \beta$ clearance by statins (Kanekiyo et al., 2012). It was also shown that statins increased $\mathrm{A} \beta$ clearance by up-regulating insulin degrading enzyme, an $A \beta$-degrading enzyme in vitro (Tamboli et al., 2010). Taking these findings together, statins could restore $\mathrm{A} \beta$ clearance, which is reported to be decreased in $\mathrm{AD}$ patients (Mawuenyega et al., 2010).

Many groups also reported that statins regulate $\mathrm{A} \beta$ production, although different mechanisms are proposed. Possible mechanisms include regulation of shedding by $\alpha / \beta / \gamma$-secretase, APPtrafficking, or degradation of APP-CTFs (C-terminal fragments of APP) through a cholesterol-dependent or isoprenoid-dependent mechanism (Kojro et al., 2001; Burns et al., 2006; Parsons et al., 2006; Ostrowski et al., 2007; Roensch et al., 2007; Won et al., 2008; Zhou et al., 2008; Guardia-Laguarta et al., 2009). Notably, these 
proposed mechanisms are all based on in vitro culture experiments or animal experiments with high doses of statins. Therefore, the effect of statins in vivo, at clinically relevant doses, has yet to be uncovered. Fluvastatin treatment at clinically relevant doses reduced $A \beta$ production by up-regulating the lysosomal degradation of APP-CTFs in the brain of young C57BL/6 mice. This effect was mediated by an isoprenoid-dependent pathway, similarly to the up-regulation of LRP1. Changes in the intracellular distribution of APP-CTFs and small GTPases, Rab5 and Rab7 might be explored to further elucidate the mechanisms of this effect (Shinohara etal., 2010). This result seems to be important, as fluvastatin, one of the brain-impermeable hydrophilic statins, also can modulate the $\mathrm{A} \beta$ production pathway in the brain at a clinical dosage. This effect might be mediated by the partial inhibition of small GTPases, as Ostrowski et al. (2007) indicated.

\section{Tau metabolism and statins}

Another key target for AD might be NFTs, where tau is hyperphosphorylated and forms a filamentous structure. The degree of neuronal loss and the severity of dementia correlate with the accumulation of NFT rather than senile plaques in AD (Braak and Braak, 1991; Arriagada et al., 1992). Several types of dementia, known as tauopathies, also manifest NFT and neuronal loss (Dickson, 2009). Regardless of whether NFT is a subsequent, parallel or separate event to A $\beta$ accumulation, NFT could be an important target for prevention and treatment of AD (Small and Duff, 2008; Jack et al., 2013). Statins were reported to reduce NFT more significantly than senile plaques in cognitively normal subjects (Li etal., 2007). This observation suggests that statins could prevent tau accumulation more readily than $A \beta$ accumulation.

Impaired cholesterol metabolism as well as oxidative and inflammatory stress seems to be involved in tau hyperphosphorylation (Schneider et al., 2004; Kitazawa et al., 2005; Michikawa, 2006; Ohm and Meske, 2006; Maccioni et al., 2010). Atorvastatin suppressed tau hyperphosphorylation induced by excess cholesterol in the rat brain (Lu etal., 2010). On the other hand, Boimel etal. (2009) found that simvastatin and atorvastatin reduced NFT and improved cognitive impairment in a tauopathy mouse model, associated with reduced inflammation. However, of note, cell culture studies showed that high doses of statins cause tau phosphorylation and cell toxicity (Hoglund et al., 2005b; Anstey et al., 2008). These findings suggest that optimal doses of statins may prevent tau hyperphosphorylation and NFT accumulation via both cholesteroland isoprenoid-dependent effects. Although a study reported that $40 \mathrm{mg} /$ day simvastatin decreased the phospho-tau level in patients with dyslipidemia without dementia (Riekse et al., 2006), other studies reported that statins including $20-80 \mathrm{mg} /$ day simvastatin failed to show a decrease of phospho-tau or total tau level in the cerebrospinal fluid (CSF) in AD patients (Sjogren et al., 2003; Hoglund etal., 2005b; Serrano-Pozo etal., 2010) and middle-aged adults with risk of AD (Carlsson et al., 2008). Taken together, further clinical studies should determine the optimal doses of statins, taking individual disease stage into account.

\section{Other genetic factors and statins}

In addition to the APOE gene, recent genome-wide association studies (GWAS) identified novel risk genes for AD (Olgiati et al., 2011). These genes include box-dependent myc-interacting protein 1 (BIN1), clusterin (CLU, also called apolipoprotein J), ATP-binding cassette transporter A7 (ABCA7), complement component receptor 1 (CR1), phosphatidylinositolbinding clathrin assembly protein (PICALM), and CD33. As BIN1 and PICALM are involved in intracellular trafficking at synapses, these genes might modulate APP trafficking or tau metabolism (Xiao etal., 2012; Chapuis et al., 2013). CR1 and CD33 are key molecules in inflammatory cells, such as microglia (Crehan etal., 2012; Griciuc et al., 2013). CLU and ABCA7 are thought to play important roles in lipid homeostasis (Tanaka etal., 2011b; Yu and Tan, 2012). Kim et al. (2013) showed that ABCA7 inactivation in macrophages reduced phagocytic clearance of $A \beta$ and exaggerated $A \beta$ accumulation in mice. Interestingly, statins are reported to enhance ABCA7dependent phagocytosis through the SREBP pathway (Tanaka et al., 2011a). These studies suggest crosstalk between statins and $\mathrm{ABCA} 7$ in $\mathrm{A} \beta$ metabolism. As these genetic factors are involved in $\mathrm{A} \beta$ metabolism, tau metabolism, inflammation, and lipid metabolism, statins may also have crosstalk with these molecules.

\section{FURTHER STUDY OF PREVENTIVE EFFECT OF STATINS FOR AD}

Whether or not statins are effective for preventing AD is yet to be confirmed. Our study showed a modest effect of a statin on $\mathrm{A} \beta$ metabolism in $\mathrm{C} 57 \mathrm{BL} / 6$ mice and APP transgenic mice (around 20\% reduction of $\mathrm{A} \beta$ level in brain; Shinohara et al., 2010). We also observed that 3 months' treatment with fluvastatin (before abundant $\mathrm{A} \beta$ plaque deposition) ameliorated impairment of spatial learning performance in APP/PS1 mice (Shinohara et al., unpublished results). These effects are most likely mediated by an isoprenoid-dependent pathway (Li et al., 2006). As cholesterol level is not readily affected by statins in rodents (Endo, 2008), larger animal models would also be required to demystify the cholesterol-dependent effects of statins (Murphy et al., 2010).

A surrogate marker for the regulation of $A \beta$ metabolism as well as other AD-associated abnormalities would help to successfully establish preventive effects on AD. Our preliminary animal studies failed to show that statin treatment affects $A \beta$ levels in the blood and CSF (unpublished data), whereas brain A $\beta$ level was reduced by a statin (Shinohara et al., 2010). These experimental results are consistent with the results of clinical studies, reporting no change in $\mathrm{A} \beta$ levels in CSF and plasma by statin use in $\mathrm{AD}$ patients and cognitively normal adults (Ishii et al., 2003; Sjogren et al., 2003; Hoglund et al., 2004, 2005a; Riekse et al., 2006; Carlsson et al., 2008; Serrano-Pozo et al., 2010). These results suggest that $A \beta$ levels in CSF and plasma would not reflect the "anti-A $\beta$ " effect of statins in the brain. Therefore, amyloid- and tau-PET (positron emission tomography) imaging (Maruyama etal., 2013; Weiner et al., 2013), and other potential CSF surrogate markers like soluble form of LRP1 (Sagare et al., 2007, 2011) - might be helpful. Several markers of oxidative stress, inflammation, or vascular plasticity and integrity could 
Table 1 | Summary of presumable beneficial actions of statin use in midlife on AD epidemiological factors.

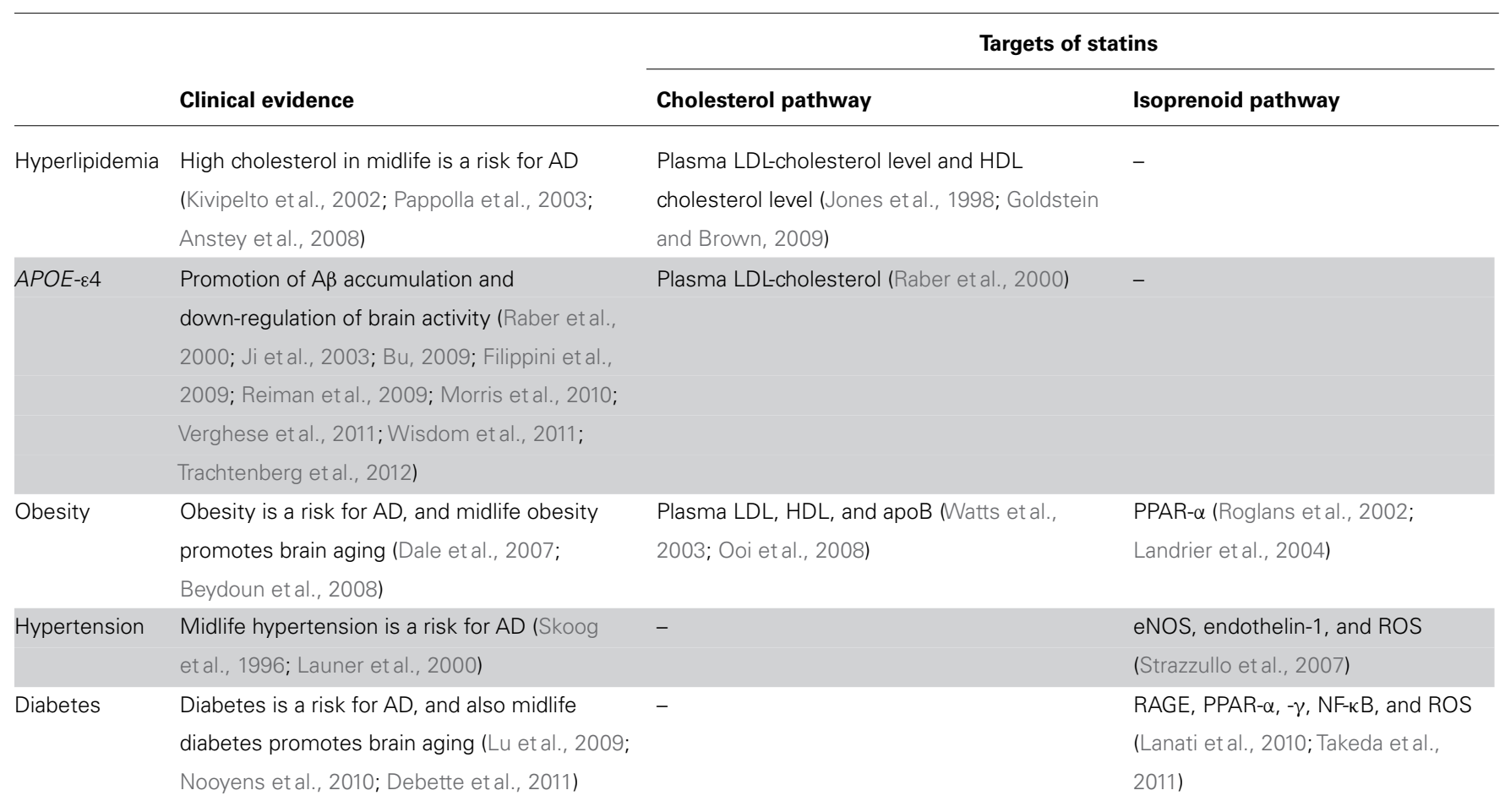

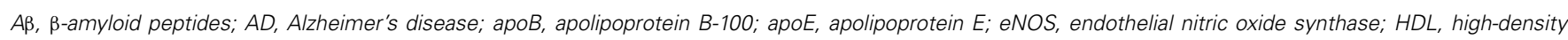

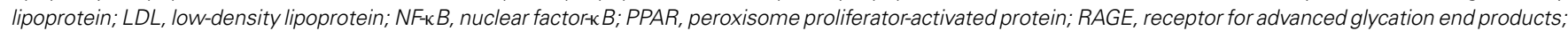
$R O S$, reactive oxygen species.

Table 2 | Summary of presumable beneficial actions of statin use in midlife on AD pathogenic stress and molecules.

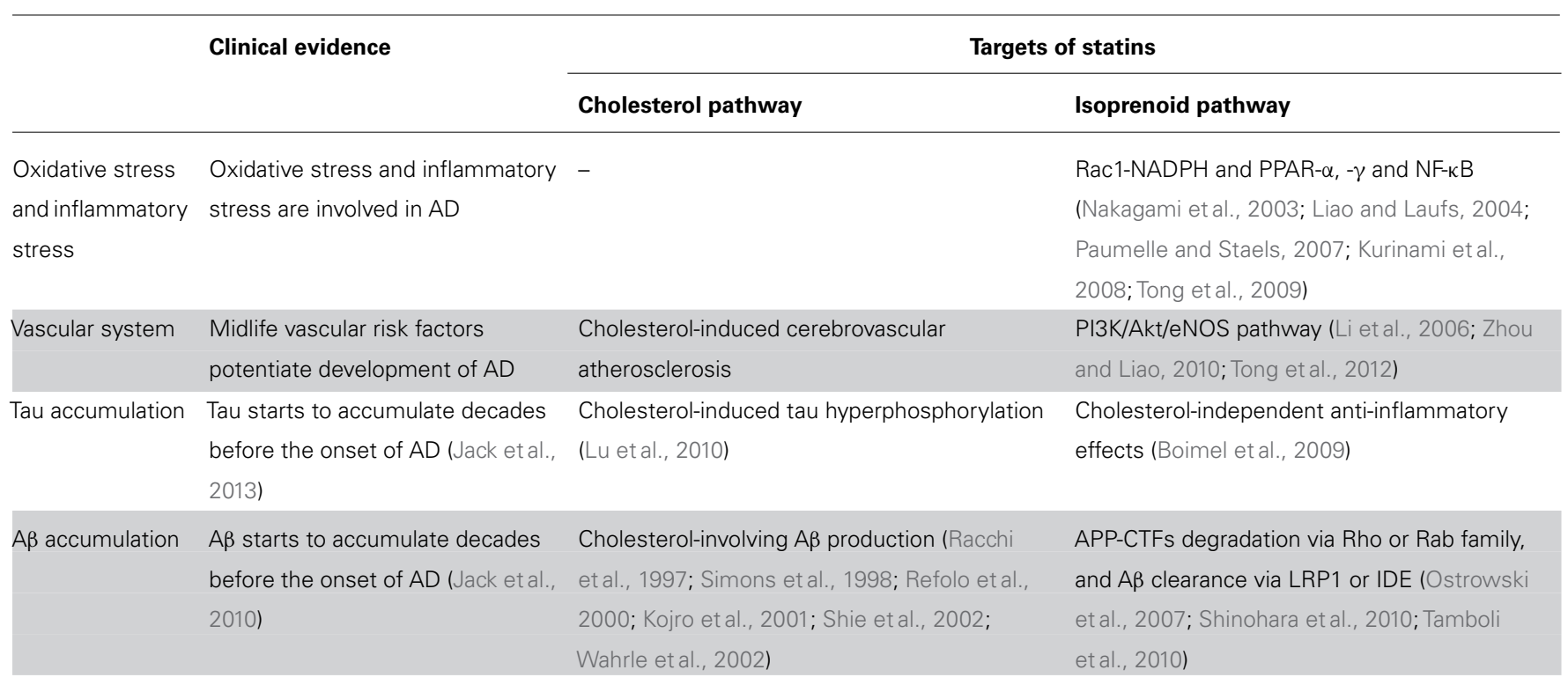

A $\beta$, $\beta$-amyloid peptides; $A D$, Alzheimer's disease; APP-CTFS, C-terminal fragments of amyloid precursor protein; eNOS, endothelial nitric oxide synthase; IDE, insulin degrading enzyme; $L R P 1, L D L R$-related protein 1; NF- $B$, nuclear factor- $B$; PPAR, peroxisome proliferator-activated protein; Rac1, Ras-related C3 botulinum toxin substrate 1; NADPH, nicotinamide adenine dinucleotide phosphate; PI3K, phosphatidylinositol-4,5-bisphosphate 3-kinase; Akt, v-akt murine thymoma viral oncogene homolog. 


\section{Genetic Risk Factors Non-genetic Risk Factors}

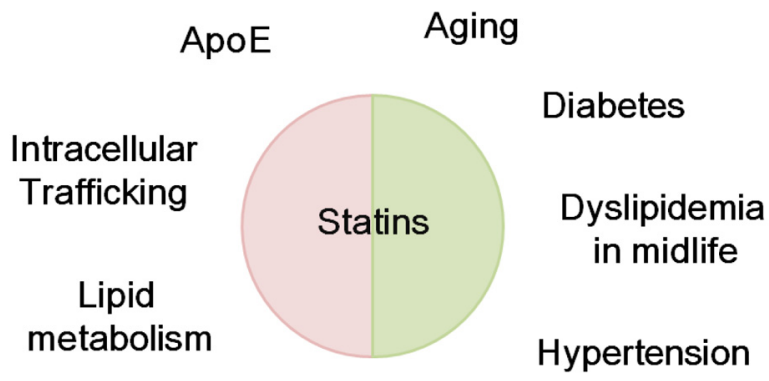

Inflammation

FIGURE 1 | Possible modification genetic and non-genetic risk factors for AD by statins. Statins might modify genetic and non-genetic risk factors for Alzheimer's disease (AD). Genetic risk factors for AD include apolipoprotein $E$ and genes involved in intracellular trafficking, lipid metabolism, and inflammation. Non-genetic risk factors include aging, diabetes, dyslipidemia in midlife, hypertension, and inflammation.

be assessed to define the beneficial preventive action of statins against $\mathrm{AD}$.

As mentioned above, statins might transiently impair cognitive function (Orsi et al., 2001; King et al., 2003; Wagstaff et al., 2003), especially where the drug is firstly administered to treat patients aged over 75 years. This adverse effect remains a rare occurrence (Rojas-Fernandez and Cameron, 2012). Considering their beneficial effects, statins should be used with close attention to the emergence of adverse effects in elderly patients.

\section{CONCLUSION}

This review describes the probable preventive actions of statins on $\mathrm{AD}$. These effects could be achievable if statins were administered decades before the onset of AD or from midlife. Such effects, if present at all, could be negligible, with a $10-50 \%$ reduction in risk being expected from the positive results of clinical studies. The preventive effects of statins on $\mathrm{AD}$ include the regulation of $\mathrm{A} \beta$ metabolism, tau metabolism, cholesterol metabolism, oxidative and inflammatory stress, and vascular plasticity and integrity, all of which are independently/interdependently involved in the pathogenesis of $\mathrm{AD}$ (Tables 1 and 2). At least some of these effects could be mediated by regulation of the isoprenoid pathway. Therefore, exploring the mechanisms by which isoprenoid metabolism influences $\mathrm{AD}$ pathogenesis may clarify the isoprenoid-dependent effects of statins on $\mathrm{AD}$ (Eckert et al., 2009). Overall, these findings reviewed here suggest that administration of statins in midlife might prevent $\mathrm{AD}$ in late life by modifying genetic and non-genetic risk factors for $\mathrm{AD}$ (Figure 1). However, it still remains unclear whether statins really prevent $\mathrm{AD}$ in prospective well-controlled clinical studies. At least, it should be clarified whether statins inhibit $A \beta$ accumulation, tau pathological features and atrophy in humans. To answer this question, a randomized controlled study using amyloid PET, tau-PET, and magnetic resonance imaging (MRI) would be useful. This clinical evaluation could help us to overcome this devastating disease.

\section{SEARCH STRATEGY AND SELECTION CRITERIA}

References for this Review were identified through searches of PubMed up to September 2013, with the search terms "((statins) OR statin) AND Alzheimer's disease," "((statins) OR statin) AND stroke," "((statins) OR statin) AND Abeta," "((statins) OR statin) AND tau," “((statins) OR statin) AND cholesterol," “((statins) OR statin) AND ((apolipoprotein E) OR apoE)," “((statins) OR statin) AND aging," "((statins) OR statin) AND ((gender) OR sex)," "((statins) OR statin) AND obesity," "((statins) OR statin) AND hypertension," "((statins) OR statin) AND diabetes," "((statins) OR statin) AND isoprenoid," “((statins) OR statin) AND ((oxidative) OR inflammatory)," "((statins) OR statin) AND (((cognitive function) OR brain) OR memory)," "((statins) OR statin) AND ((vasculature) OR vascular)," and "((statins) OR statin) AND (((((BIN1) OR PICALM) OR CD33) OR CR1) OR CLU) OR ABCA7)." Only papers published in English were reviewed. Clinical studies as well as animal or cell culture studies were included. Evidence independently reported by several studies (e.g., metaanalysis) was more emphasized than evidence reported by a single study.

\section{REFERENCES}

Akiyama, H., and McGeer, P. L. (2004). Specificity of mechanisms for plaque removal after A beta immunotherapy for Alzheimer disease. Nat. Med. 10, 117-118; author reply 8-9. doi: 10.1038/nm0204-117

Alzheimer's Association. (2013). 2013 Alzheimer's disease facts and figures. Alzheimers Dement. 9, 208-245. doi: 10.1016/j.jalz.2013.02.003

Amarenco, P., and Labreuche, J. (2009). Lipid management in the prevention of stroke: review and updated meta-analysis of statins for stroke prevention. Lancet Neurol. 8, 453-463. doi: 10.1016/S1474-4422(09)70058-4

Anstey, K. J., Lipnicki, D. M., and Low, L. F. (2008). Cholesterol as a risk factor for dementia and cognitive decline: a systematic review of prospective studies with meta-analysis. Am. J. Geriatr. Psychiatry 16, 343-354. doi: 10.1097/01.JGP.0000310778.20870.ae

Arriagada, P. V., Growdon, J. H., Hedley-Whyte, E. T., and Hyman, B. T. (1992). Neurofibrillary tangles but not senile plaques parallel duration and severity of Alzheimer's disease. Neurology 42(Pt 1), 631-639. doi: 10.1212/WNL.42.3.631

Arvanitakis, Z., Schneider, J. A., Wilson, R. S., Bienias, J. L., Kelly, J. F., Evans, D. A., etal. (2008). Statins, incident Alzheimer disease, change in cognitive function, and neuropathology. Neurology 70(Pt 2), 1795-1802. doi: 10.1212/01.wnl.0000288181.00826.63

Ashford, J. W. (2004). APOE genotype effects on Alzheimer's disease onset and epidemiology. J. Mol. Neurosci. 23, 157-165. doi: 10.1385/JMN:23:3:157

Ballard, C., Gauthier, S., Corbett, A., Brayne, C., Aarsland, D., and Jones, E. (2011). Alzheimer's disease. Lancet 377, 1019-1031. doi: 10.1016/S0140-6736(10) 61349-9

Beach, T. G., Wilson, J. R., Sue, L. I., Newell, A., Poston, M., Cisneros, R., et al. (2007). Circle of Willis atherosclerosis: association with Alzheimer's disease, neuritic plaques and neurofibrillary tangles. Acta Neuropathol. 113, 13-21. doi: 10.1007/s00401-006-0136-y

Bell, R. D., and Zlokovic, B. V. (2009). Neurovascular mechanisms and blood-brain barrier disorder in Alzheimer's disease. Acta Neuropathol. 118, 103-113. doi: 10.1007/s00401-009-0522-3

Bennett, S., Grant, M. M., and Aldred, S. (2009). Oxidative stress in vascular dementia and Alzheimer's disease: a common pathology. J. Alzheimers Dis. 17, 245-257. doi: 10.3233/JAD-2009-1041

Bettermann, K., Arnold, A. M., Williamson, J., Rapp, S., Sink, K., Toole, J. F., et al. (2012). Statins, risk of dementia, and cognitive function: secondary analysis of the ginkgo evaluation of memory study. J. Stroke Cerebrovasc. Dis. 21, 436-444. doi: 10.1016/j.jstrokecerebrovasdis.2010.11.002

Beydoun, M. A., Beydoun, H. A., and Wang, Y. (2008). Obesity and central obesity as risk factors for incident dementia and its subtypes: a systematic review and meta-analysis. Obes. Rev. 9, 204-218. doi: 10.1111/j.1467-789X.2008. 00473.x 
Boimel, M., Grigoriadis, N., Lourbopoulos, A., Touloumi, O., Rosenmann, D., Abramsky, O., et al. (2009). Statins reduce the neurofibrillary tangle burden in a mouse model of tauopathy. J. Neuropathol. Exp. Neurol. 68, 314-325. doi: 10.1097/NEN.0b013e31819ac3cb

Braak, H., and Braak, E. (1991). Neuropathological stageing of Alzheimer-related changes. Acta Neuropathol. 82, 239-259. doi: 10.1007/BF00308809

Breitner, J. C. S., Haneuse, S. J. P. A., Walker, R., Dublin, S., Crane, P. K., Gray, S. L., et al. (2009). Risk of dementia and AD with prior exposure to NSAIDs in an elderly community-based cohort. Neurology 72, 1899-1905. doi: 10.1212/WNL.0b013e3181a18691

$\mathrm{Bu}, \mathrm{G}$. (2009). Apolipoprotein E and its receptors in Alzheimer's disease: pathways, pathogenesis and therapy. Nat. Rev. Neurosci. 10, 333-344. doi: 10.1038/nrn2620

Burns, A. (2009). Alzheimer's disease: on the verges of treatment and prevention. Lancet Neurol. 8, 4-5. doi: 10.1016/S1474-4422(08)70271-0

Burns, M. P., Igbavboa, U., Wang, L., Wood, W. G., and Duff, K. (2006). Cholesterol distribution, not total levels, correlate with altered amyloid precursor protein processing in statin-treated mice. Neuromol. Med. 8, 319-328. doi 10.1385/NMM:8:3:319

Butterfield, D. A., Barone, E., and Mancuso, C. (2011). Cholesterol-independent neuroprotective and neurotoxic activities of statins: perspectives for statin use in Alzheimer disease and other age-related neurodegenerative disorders. Pharmacol. Res. 64, 180-186. doi: 10.1016/j.phrs.2011.04.007

Carlsson, C. M., Gleason, C. E., Hess, T. M., Moreland, K. A., Blazel, H. M., Koscik, R. L., et al. (2008). Effects of simvastatin on cerebrospinal fluid biomarkers and cognition in middle-aged adults at risk for Alzheimer's disease. J. Alzheimers Dis 13, 187-197.

Chapuis, J., Hansmannel, F., Gistelinck, M., Mounier, A., Van Cauwenberghe, C. Kolen, K. V., et al. (2013). Increased expression of BIN1 mediates Alzheimer genetic risk by modulating tau pathology. Mol. Psychiatry 18, 1225-1234. doi: 10.1038/mp.2013.1

Crehan, H., Holton, P., Wray, S., Pocock, J., Guerreiro, R., and Hardy, J. (2012) Complement receptor 1 (CR1) and Alzheimer's disease. Immunobiology 217, 244250. doi: 10.1016/j.imbio.2011.07.017

Crouse, J. R. III, Byington, R. P., Hoen, H. M., and Furberg, C. D. (1997). Reductase inhibitor monotherapy and stroke prevention. Arch. Intern. Med. 157, 1305-1310 doi: 10.1001/archinte.1997.00440330039004

Cullen, P., Cignarella, A., Brennhausen, B., Mohr, S., Assmann, G., and von Eckardstein, A. (1998). Phenotype-dependent differences in apolipoprotein E metabolism and in cholesterol homeostasis in human monocyte-derived macrophages. J. Clin. Invest. 101, 1670-1677. doi: 10.1172/JCI119887

Cutler, R. G., Kelly, J., Storie, K., Pedersen, W. A., Tammara, A., Hatanpaa, K., et al. (2004). Involvement of oxidative stress-induced abnormalities in ceramide and cholesterol metabolism in brain aging and Alzheimer's disease. Proc. Natl. Acad. Sci. U.S.A. 101, 2070-2075. doi: 10.1073/pnas.0305799101

Dale, K. M., Coleman, C. I., Shah, S. A., Patel, A. A., Kluger, J., and White, C. M. (2007). Impact of gender on statin efficacy. Curr. Med. Res. Opin. 23, 565-574 doi: 10.1185/030079906X167516

Deane, R. J. (2012). Is RAGE still a therapeutic target for Alzheimer's disease? Future Med. Chem. 4, 915-925. doi: 10.4155/fmc.12.51

Debette, S., Seshadri, S., Beiser, A., Au, R., Himali, J. J., Palumbo, C., et al. (2011). Midlife vascular risk factor exposure accelerates structural brain aging and cognitive decline. Neurology 77, 461-468. doi: 10.1212/WNL.0b013e31822 $7 \mathrm{~b} 227$

De Caterina, R., Scarano, M., Marfisi, R., Lucisano, G., Palma, F., Tatasciore, A., et al (2010). Cholesterol-lowering interventions and stroke: insights from a metaanalysis of randomized controlled trials. J. Am. Coll. Cardiol. 55, 198-211. doi: 10.1016/j.jacc.2009.07.062

Dickson, D. W. (2009). Neuropathology of non-Alzheimer degenerative disorders. Int. J. Clin. Exp. Pathol. 3, 1-23.

Dietschy, J. M., and Turley, S. D. (2004). Thematic review series: brain lipids. Cholesterol metabolism in the central nervous system during early development and in the mature animal. J. Lipid Res. 45, 1375-1397. doi: 10.1194/jlr.R400004JLR200

Downs, J. R., Clearfield, M., Weis, S., Whitney, E., Shapiro, D. R., Beere, P. A., et al. (1998). Primary prevention of acute coronary events with lovastatin in men and women with average cholesterol levels: results of AFCAPS/TexCAPS. Air Force/Texas Coronary Atherosclerosis Prevention Study. JAMA 279, 1615-1622. doi: $10.1001 /$ jama.279.20.1615
Dufouil, C., Richard, F., Fievet, N., Dartigues, J. F., Ritchie, K., Tzourio, C., etal. (2005). APOE genotype, cholesterol level, lipid-lowering treatment, and dementia: the Three-City Study. Neurology 64, 1531-1538. doi: 10.1212/01.WNL.0000160114.42643.31

Eckert, G. P., Hooff, G. P., Strandjord, D. M., Igbavboa, U., Volmer, D. A., Muller, W. E., et al. (2009). Regulation of the brain isoprenoids farnesyl- and geranylgeranylpyrophosphate is altered in male Alzheimer patients. Neurobiol. Dis. 35, 251-257. doi: 10.1016/j.nbd.2009.05.005

Endo, A. (2004). The discovery and development of HMG-CoA reductase inhibitors. 1992. Atheroscler. Suppl. 5, 67-80. doi: 10.1016/j.atherosclerosissup.2004.08.026

Endo, A. (2008). A gift from nature: the birth of the statins. Nat. Med. 14, 1050-1052. doi: $10.1038 / \mathrm{nm} 1008-1050$

Evans, M. A., and Golomb, B. A. (2009). Statin-associated adverse cognitive effects: survey results from 171 patients. Pharmacotherapy 29, 800-811. doi: 10.1592/phco.29.7.800

Evans, R. M., Emsley, C. L., Gao, S., Sahota, A., Hall, K. S., Farlow, M. R., et al. (2000). Serum cholesterol, APOE genotype, and the risk of Alzheimer's disease: a population-based study of African Americans. Neurology 54, 240. doi: 10.1212/WNL.54.1.240

Fan, Q. W., Yu, W., Senda, T., Yanagisawa, K., and Michikawa, M. (2001) Cholesterol-dependent modulation of tau phosphorylation in cultured neurons. J. Neurochem. 76, 391-400. doi: 10.1046/j.1471-4159.2001.00063.x

Fassbender, K., Simons, M., Bergmann, C., Stroick, M., Lutjohann, D., Keller, P., et al. (2001). Simvastatin strongly reduces levels of Alzheimer's disease beta-amyloid peptides Abeta 42 and Abeta 40 in vitro and in vivo. Proc. Natl. Acad. Sci. U.S.A. 98, 5856-5861. doi: 10.1073/pnas.081620098

Feldman, H. H., Doody, R. S., Kivipelto, M., Sparks, D. L., Waters, D. D., Jones, R. W., et al. (2010). Randomized controlled trial of atorvastatin in mild to moderate Alzheimer disease: LEADe. Neurology 74, 956-964. doi: 10.1212/WNL.0b013e3181d6476a

Filippini, N., MacIntosh, B. J., Hough, M. G., Goodwin, G. M., Frisoni, G. B., Smith, S. M., et al. (2009). Distinct patterns of brain activity in young carriers of the APOE-epsilon4 allele. Proc. Natl. Acad. Sci. U.S.A. 106, 7209-7214. doi: 10.1073/pnas.0811879106

Goldstein, J. L., and Brown, M. S. (2009). The LDL receptor. Arterioscler. Thromb. Vasc. Biol. 29, 431-438. doi: 10.1161/ATVBAHA.108.179564

Gomez-Isla, T., Blesa, R., Boada, M., Clarimon, J., Del Ser, T., Domenech, G., et al. (2008). A randomized, double-blind, placebo controlled-trial of triflusal in mild cognitive impairment: the TRIMCI study. Alzheimer Dis. Assoc. Disord. 22, 21-29. doi: 10.1097/WAD.0b013e3181611024

Griciuc, A., Serrano-Pozo, A., Parrado, A. R., Lesinski, A. N., Asselin, C. N., Mullin, K., et al. (2013). Alzheimer's disease risk gene CD33 inhibits microglial uptake of amyloid beta. Neuron 78, 631-643. doi: 10.1016/j.neuron.2013.04.014

Guardia-Laguarta, C., Coma, M., Pera, M., Clarimon, J., Sereno, L., Agullo, J. M., et al. (2009). Mild cholesterol depletion reduces amyloid-beta production by impairing APP trafficking to the cell surface. J. Neurochem. 110, 220-230. doi: 10.1111/j.1471-4159.2009.06126.x

Haag, M. D., Hofman, A., Koudstaal, P. J., Stricker, B. H., and Breteler, M. M. (2009). Statins are associated with a reduced risk of Alzheimer disease regardless of lipophilicity. The Rotterdam Study. J. Neurol. Neurosurg. Psychiatry 80, 13-17. doi: 10.1136/jnnp.2008.150433

Heart Protection Study Collaborative Group. (2002). MRC/BHF Heart Protection Study of cholesterol lowering with simvastatin in 20,536 high-risk individuals: a randomised placebo-controlled trial. Lancet 360, 7-22. doi: 10.1016/S0140 6736(02)09327-3

Heneka, M. T., O’Banion, M. K., Terwel, D., and Kummer, M. P. (2010). Neuroinflammatory processes in Alzheimer's disease. J. Neural Transm. 117, 919-947. doi: 10.1007/s00702-010-0438-z

Hoglund, K., Syversen, S., Lewczuk, P., Wallin, A., Wiltfang, J., and Blennow, K. (2005a). Statin treatment and a disease-specific pattern of beta-amyloid peptides in Alzheimer's disease. Exp. Brain Res. 164, 205-214. doi: 10.1007/s00221-0052243-8

Hoglund, K., Thelen, K. M., Syversen, S., Sjogren, M., von Bergmann, K., Wallin, A., et al. (2005b). The effect of simvastatin treatment on the amyloid precursor protein and brain cholesterol metabolism in patients with Alzheimer's disease. Dement. Geriatr. Cogn. Disord. 19, 256-265. doi: 10.1159/000084550

Hoglund, K., Wiklund, O., Vanderstichele, H., Eikenberg, O., Vanmechelen, E., and Blennow, K. (2004). Plasma levels of beta-amyloid (1-40), beta-amyloid 
(1-42), and total beta-amyloid remain unaffected in adult patients with hypercholesterolemia after treatment with statins. Arch. Neurol. 61, 333-337. doi: 10.1001/archneur.61.3.333

Holmes, C., Boche, D., Wilkinson, D., Yadegarfar, G., Hopkins, V., Bayer, A., et al. (2008). Long-term effects of A $\beta 42$ immunisation in Alzheimer's disease: followup of a randomised, placebo-controlled phase I trial. Lancet 372, 216-223. doi: 10.1016/S0140-6736(08)61075-2

Hubacek, J. A., and Vrablik, M. (2011). Effect of apolipoprotein E polymorphism on statin-induced decreases in plasma lipids and cardiovascular events. Drug Metab. Drug Interact. 26, 13-20. doi: 10.1515/dmdi.2011.107

Iadecola, C. (2004). Neurovascular regulation in the normal brain and in Alzheimer's disease. Nat. Rev. Neurosci. 5, 347-360. doi: 10.1038/nrn1387

Imbimbo, B. P., Solfrizzi, V., and Panza, F. (2010). Are NSAIDs useful to treat Alzheimer's disease or mild cognitive impairment? Front. Aging Neurosci. 2:19. doi: 10.3389/fnagi.2010.00019

Ishii, K., Tokuda, T., Matsushima, T., Miya, F., Shoji, S., Ikeda, S., et al. (2003). Pravastatin at $10 \mathrm{mg} /$ day does not decrease plasma levels of either amyloidbeta (Abeta) 40 or Abeta 42 in humans. Neurosci. Lett. 350, 161-164. doi: 10.1016/S0304-3940(03)00895-4

Jack, C. R. Jr., Knopman, D. S., Jagust, W. J., Petersen, R. C., Weiner, M. W., Aisen, P. S., et al. (2013). Tracking pathophysiological processes in Alzheimer's disease: an updated hypothetical model of dynamic biomarkers. Lancet Neurol. 12, 207-216. doi: 10.1016/S1474-4422(12)70291-0

Jack, C. R. Jr., Knopman, D. S., Jagust, W. J., Shaw, L. M., Aisen, P. S., Weiner, M. W., et al. (2010). Hypothetical model of dynamic biomarkers of the Alzheimer's pathological cascade. Lancet Neurol. 9, 119-128. doi: 10.1016/S1474-4422(09)70299-6

Jarvik, G. P., Wijsman, E. M., Kukull, W. A., Schellenberg, G. D., Yu, C., and Larson, E. B. (1995). Interactions of apolipoprotein E genotype, total cholesterol level, age, and sex in prediction of Alzheimer's disease. Neurology 45, 1092-1096. doi: 10.1212/WNL.45.6.1092

Ji, Y., Gong, Y., Gan, W., Beach, T., Holtzman, D. M., and Wisniewski, T. (2003). Apolipoprotein E isoform-specific regulation of dendritic spine morphology in apolipoprotein E transgenic mice and Alzheimer's disease patients. Neuroscience 122, 305-315. doi: 10.1016/j.neuroscience.2003.08.007

Jick, H., Zornberg, G. L., Jick, S. S., Seshadri, S., and Drachman, D. A. (2000). Statins and the risk of dementia. Lancet 356, 1627-1631. doi: 10.1016/S01406736(00)03155-X

Jones, P., Kafonek, S., Laurora, I., and Hunninghake, D. (1998). Comparative dose efficacy study of atorvastatin versus simvastatin, pravastatin, lovastatin, and fluvastatin in patients with hypercholesterolemia (the CURVES study). Am. J. Cardiol. 81, 582-587. doi: 10.1016/S0002-9149(97)00965-X

Jorm, A. F., and Jolley, D. (1998). The incidence of dementia. Neurology 51, 728-733. doi: 10.1212/WNL.51.3.728

Kanekiyo, T., Liu, C. C., Shinohara, M., Li, J., and Bu, G. (2012). LRP1 in brain vascular smooth muscle cells mediates local clearance of Alzheimer's amyloidbeta. J. Neurosci. 32, 16458-16465. doi: 10.1523/JNEUROSCI.3987-12.2012

Kearney, P. M., Blackwell, L., Collins, R., Keech, A., Simes, J., Peto, R., et al (2008). Efficacy of cholesterol-lowering therapy in 18,686 people with diabetes in 14 randomised trials of statins: a meta-analysis. Lancet 371, 117-125. doi: 10.1016/S0140-6736(08)60104-X

Kim, W. S., Li, H., Ruberu, K., Chan, S., Elliott, D. A., Low, J. K., et al. (2013). Deletion of Abca7 increases cerebral amyloid-beta accumulation in the J20 mouse model of Alzheimer's disease. J. Neurosci. 33, 4387-4394. doi: 10.1523/JNEUROSCI.416512.2013

King, D. S., Wilburn, A. J., Wofford, M. R., Harrell, T. K., Lindley, B. J., and Jones, D. W. (2003). Cognitive impairment associated with atorvastatin and simvastatin. Pharmacotherapy 23, 1663-1667. doi: 10.1592/phco.23.15.1663.31953

Kitazawa, M., Oddo, S., Yamasaki, T. R., Green, K. N., and LaFerla, F. M. (2005). Lipopolysaccharide-induced inflammation exacerbates tau pathology by a cyclindependent kinase 5-mediated pathway in a transgenic model of Alzheimer's disease. J. Neurosci. 25, 8843-8853. doi: 10.1523/JNEUROSCI.2868-05. 2005

Kivipelto, M., Helkala, E.-L., Laakso, M. P., Hänninen, T., Hallikainen, M., Alhainen, K., et al. (2002). Apolipoprotein E $\epsilon 4$ allele, elevated midlife total cholesterol level, and high midlife systolic blood pressure are independent risk factors for late-life Alzheimer disease. Ann. Intern. Med. 137, 149-155. doi: 10.7326/0003-4819-1373-200208060-00006
Kojro, E., Gimpl, G., Lammich, S., Marz, W., and Fahrenholz, F. (2001). Low cholesterol stimulates the nonamyloidogenic pathway by its effect on the alpha -secretase ADAM 10. Proc. Natl. Acad. Sci. U.S.A. 98, 5815-5820. doi: 10.1073/pnas.081612998

Kolovou, G., Anagnostopoulou, K., Mikhailidis, D. P., and Cokkinos, D. V. (2008). Apolipoprotein E knockout models. Curr. Pharm. Des. 14, 338-351. doi: 10.2174/138161208783497769

Kolovou, G. D., and Anagnostopoulou, K. K. (2007). Apolipoprotein E polymorphism, age and coronary heart disease. Ageing Res. Rev. 6, 94-108. doi: 10.1016/j.arr.2006.11.001

Kölsch, H., Heun, R., Jessen, F., Popp, J., Hentschel, F., Maier, W., et al. (2010). Alterations of cholesterol precursor levels in Alzheimer's disease. Biochim. Biophys. Acta 1801, 945-950. doi: 10.1016/j.bbalip.2010.03.001

Kölsch, H., Heun, R., Kerksiek, A., Bergmann, K. V., Maier, W., and Lütjohann, D. (2004). Altered levels of plasma 24S- and 27-hydroxycholesterol in demented patients. Neurosci. Lett. 368, 303-308. doi: 10.1016/j.neulet.2004. 07.031

Kurata, T., Kawai, H., Miyazaki, K., Kozuki, M., Morimoto, N., Ohta, Y., et al. (2012). Statins have therapeutic potential for the treatment of Alzheimer's disease, likely via protection of the neurovascular unit in the AD brain. J. Neurol. Sci.322, 59-63. doi: 10.1016/j.jns.2012.06.011

Kurinami, H., Sato, N., Shinohara, M., Takeuchi, D., Takeda, S., Shimamura, M., et al. (2008). Prevention of amyloid beta-induced memory impairment by fluvastatin, associated with the decrease in amyloid beta accumulation and oxidative stress in amyloid beta injection mouse model. Int. J. Mol. Med. 21, 531-537. doi: 10.3892/ijmm.21.5.531

Lanati, N., Emanuele, E., Brondino, N., and Geroldi, D. (2010). Soluble RAGE-modulating drugs: state-of-the-art and future perspectives for targeting vascular inflammation. Curr. Vasc. Pharmacol. 8, 86-92. doi: $10.2174 / 157016110790226642$

Landrier, J. F., Thomas, C., Grober, J., Duez, H., Percevault, F., Souidi, M., et al. (2004). Statin induction of liver fatty acid-binding protein (L-FABP) gene expression is peroxisome proliferator-activated receptor-alpha-dependent. J. Biol. Chem. 279, 45512-45518. doi: 10.1074/jbc.M407461200

Launer, L. J., Hughes, T., Yu, B., Masaki, K., Petrovitch, H., Ross, G. W., et al. (2010). Lowering midlife levels of systolic blood pressure as a public health strategy to reduce late-life dementia: perspective from the Honolulu Heart Program/Honolulu Asia Aging Study. Hypertension 55, 1352-1359. doi: 10.1161/HYPERTENSIONAHA.109.147389

Launer, L. J., Ross, G. W., Petrovitch, H., Masaki, K., Foley, D., White, L. R., et al. (2000). Midlife blood pressure and dementia: the Honolulu-Asia aging study. Neurobiol. Aging 21, 49-55. doi: 10.1016/S0197-4580(00)00096-8

Leoni, V., Shafaati, M., Salomon, A., Kivipelto, M., Bjorkhem, I., and Wahlund, L. O. (2006). Are the CSF levels of 24S-hydroxycholesterol a sensitive biomarker for mild cognitive impairment? Neurosci. Lett. 397, 83-87. doi: 10.1016/j.neulet.2005.11.046

Li, G., Higdon, R., Kukull, W. A., Peskind, E., Van Valen Moore, K., Tsuang, D., etal. (2004). Statin therapy and risk of dementia in the elderly: a community-based prospective cohort study. Neurology 63, 1624-1628. doi: 10.1212/01.WNL.0000142963.90204.58

Li, G., Larson, E. B., Sonnen, J. A., Shofer, J. B., Petrie, E. C., Schantz, A., et al. (2007). Statin therapy is associated with reduced neuropathologic changes of Alzheimer disease. Neurology 69, 878-885. doi: 10.1212/01.wnl.0000277657.95487.1c

Li, G., Shofer, J. B., Rhew, I. C., Kukull, W. A., Peskind, E. R., McCormick, W., et al. (2010a). Age-varying association between statin use and incident Alzheimer's disease. J. Am. Geriatr. Soc. 58, 1311-1317. doi: 10.1111/j.1532-5415.2010.02906.x

Li, N. C., Lee, A., Whitmer, R. A., Kivipelto, M., Lawler, E., Kazis, L. E., et al. (2010b). Use of angiotensin receptor blockers and risk of dementia in a predominantly male population: prospective cohort analysis. BMJ 340, b5465. doi: 10.1136/bmj. b5465

Li, L., Cao, D., Kim, H., Lester, R., and Fukuchi, K. (2006). Simvastatin enhances learning and memory independent of amyloid load in mice. Ann. Neurol. 60, 729-739. doi: 10.1002/ana.21053

Liao, J. K., and Laufs, U. (2004). Pleiotropic effects of statins. Annu. Rev. Pharmacol. Toxicol. 45, 89-118. doi: 10.1146/annurev.pharmtox.45.120403.095748

Lu, F., Li, X., Suo, A. Q., and Zhang, J. W. (2010). Inhibition of tau hyperphosphorylation and beta amyloid production in rat brain by oral administration of atorvastatin. Chin. Med. J. (Engl.) 123, 1864-1870. 
Lu, F.-P., Lin, K.-P., and Kuo, H.-K. (2009). Diabetes and the risk of multi-system aging phenotypes: a systematic review and meta-analysis. PLoS ONE 4:e4144. doi: 10.1371/journal.pone.0004144

Lucic, D., Huang, Z. H., Gu, D. S., Altenburg, M. K., Maeda, N., and Mazzone, T. (2007). Regulation of macrophage apoE secretion and sterol efflux by the LDL receptor. J. Lipid Res. 48, 366-372. doi: 10.1194/jlr.M600259-JLR200

Lyketsos, C. G., Breitner, J. C., Green, R. C., Martin, B. K., Meinert, C., Piantadosi, S., et al. (2007). Naproxen and celecoxib do not prevent AD in early results from a randomized controlled trial. Neurology 68, 1800-1808. doi: 10.1212/01.wnl.0000260269.93245.d2

Mabuchi, H., Haba, T., Tatami, R., Miyamoto, S., Sakai, Y., Wakasugi, T., et al. (1981). Effect of an inhibitor of 3-hydroxy-3-methyglutaryl coenzyme A reductase on serum lipoproteins and ubiquinone-10-levels in patients with familial hypercholesterolemia. N. Engl. J. Med. 305, 478-482. doi: 10.1056/NEJM198108273050902

Maccioni, R. B., Farias, G., Morales, I., and Navarrete, L. (2010). The revitalized tau hypothesis on Alzheimer's disease. Arch. Med. Res. 41, 226-231. doi 10.1016/j.arcmed.2010.03.007

Maruyama, M., Shimada, H., Suhara, T., Shinotoh, H., Ji, B., Maeda, J., et al. (2013). Imaging of tau pathology in a tauopathy mouse model and in Alzheimer patients compared to normal controls. Neuron 79, 1094-1108. doi: 10.1016/j.neuron.2013.07.037

Masters, C. L., and Beyreuther, K. (2006). Alzheimer's centennial legacy: prospects for rational therapeutic intervention targeting the Abeta amyloid pathway. Brain 129(Pt 11), 2823-2839. doi: 10.1093/brain/awl251

Mawuenyega, K. G., Sigurdson, W., Ovod, V., Munsell, L., Kasten, T., Morris, J. C. et al. (2010). Decreased clearance of CNS beta-amyloid in Alzheimer's disease. Science 330, 9. doi: 10.1126/science.1197623

Michikawa, M. (2006). Role of cholesterol in amyloid cascade: cholesteroldependent modulation of tau phosphorylation and mitochondrial function. Acta Neurol. Scand. Suppl. 185, 21-26. doi: 10.1111/j.1600-0404.2006.00681.x

Morris, J. C., Roe, C. M., Xiong, C., Fagan, A. M., Goate, A. M., Holtzman, D. M., et al. (2010). APOE predicts amyloid-beta but not tau Alzheimer pathology in cognitively normal aging. Ann. Neurol. 67, 122-131. doi: 10.1002/ana.21843

Mulder, M., Ravid, R., Swaab, D. F., de Kloet, E. R., Haasdijk, E. D., Julk, J., et al. (1998). Reduced levels of cholesterol, phospholipids, and fatty acids in cerebrospinal fluid of Alzheimer disease patients are not related to apolipoprotein E4. Alzheimer Dis. Assoc. Disord. 12, 198-203. doi: 10.1097/00002093-19980900000012

Murphy, M. P., Morales, J., Beckett, T. L., Astarita, G., Piomelli, D., Weidner, A., et al. (2010). Changes in cognition and amyloid-beta processing with long term cholesterol reduction using atorvastatin in aged dogs. J. Alzheimers Dis. 22, 135 150. doi: 10.3233/JAD-2010-100639

Nakagami, H., Jensen, K. S., and Liao, J. K. (2003). A novel pleiotropic effect of statins: prevention of cardiac hypertrophy by cholesterol-independent mechanisms. Ann. Med. 35, 398-403. doi: 10.1080/07853890310001294

Nooyens, A. C., Baan, C. A., Spijkerman, A. M., and Verschuren, W. M. (2010). Type 2 diabetes and cognitive decline in middle-aged men and women: the Doetinchem Cohort Study. Diabetes Care 33, 1964-1969. doi: 10.2337/dc09-2038

Notkola, I. L., Sulkava, R., Pekkanen, J., Erkinjuntti, T., Ehnholm, C., Kivinen, P., et al. (1998). Serum total cholesterol, apolipoprotein E epsilon 4 allele, and Alzheimer's disease. Neuroepidemiology 17, 14-20. doi: 10.1159/000026149

Odawara, M., Yamazaki, T., Kishimoto, J., Ito, C., Noda, M., Terauchi, Y., et al. (2013). "Pitavastatin for the delay or prevention of diabetes development in individuals with impaired glucose tolerance," in 73rd Scientific Sessions, American Diabetes Association. Abstract number 61-LB.

Ohm, T. G., and Meske, V. (2006). Cholesterol, statins and tau. Acta Neurol. Scand. Suppl. 185, 93-101. doi: 10.1111/j.1600-0404.2006.00692.x

Olgiati, P., Politis, A. M., Papadimitriou, G. N., De Ronchi, D., and Serretti, A. (2011). Genetics of late-onset Alzheimer's disease: update from the alzgene database and analysis of shared pathways. Int. J. Alzheimers Dis. 2011, 832379. doi: 10.4061/2011/832379

Ooi, E. M., Barrett, P. H., Chan, D. C., Nestel, P. J., and Watts, G. F. (2008). Dose-dependent effect of rosuvastatin on apolipoprotein B-100 kinetics in the metabolic syndrome. Atherosclerosis 197, 139-146. doi: 10.1016/j.atherosclerosis.2007.03.004

Orsi, A., Sherman, O., and Woldeselassie, Z. (2001). Simvastatin-associated memory loss. Pharmacotherapy 21, 767-769. doi: 10.1592/phco.21.7.767.34577
Ostrowski, S. M., Wilkinson, B. L., Golde, T. E., and Landreth, G. (2007). Statins reduce amyloid-beta production through inhibition of protein isoprenylation. J. Biol. Chem. 282, 26832-26844. doi: 10.1074/jbc.M702640200

Padala, K. P., Padala, P. R., McNeilly, D. P., Geske, J. A., Sullivan, D. H., and Potter, J. F. (2012). The effect of HMG-CoA reductase inhibitors on cognition in patients with Alzheimer's dementia: a prospective withdrawal and rechallenge pilot study. Am. J. Geriatr. Pharmacother. 10, 296-302. doi: 10.1016/j.amjopharm.2012.08.002

Papassotiropoulos, A., Lütjohann, D., Bagli, M., Locatelli, S., Jessen, F., Buschfort, R., et al. (2002). 24S-hydroxycholesterol in cerebrospinal fluid is elevated in early stages of dementia. J. Psychiatr. Res. 36, 27-32. doi: 10.1016/S00223956(01)00050-4

Pappolla, M. A., Bryant-Thomas, T. K., Herbert, D., Pacheco, J., Fabra Garcia, M., Manjon, M., et al. (2003). Mild hypercholesterolemia is an early risk factor for the development of Alzheimer amyloid pathology. Neurology 61, 199-205. doi: 10.1212/01.WNL.0000070182.02537.84

Park, I.-H., Hwang, E. M., Hong, H. S., Boo, J. H., Oh, S. S., Lee, J., et al. (2003). Lovastatin enhances A[beta] production and senile plaque deposition in female Tg2576 mice. Neurobiol. Aging 24, 637-643. doi: 10.1016/S0197-4580(02) 00155-0

Parsons, R. B., Price, G. C., Farrant, J. K., Subramaniam, D., Adeagbo-Sheikh, J., and Austen, B. M. (2006). Statins inhibit the dimerization of beta-secretase via both isoprenoid- and cholesterol-mediated mechanisms. Biochem. J. 399, 205-214. doi: 10.1042/BJ20060655

Paumelle, R., Blanquart, C., Briand, O., Barbier, O., Duhem, C., Woerly, G., et al. (2006). Acute antiinflammatory properties of statins involve peroxisome proliferator-activated receptor-alpha via inhibition of the protein kinase $\mathrm{C}$ signaling pathway. Circ. Res. 98, 361-369. doi: 10.1161/01.RES.0000202706.70992.95

Paumelle, R., and Staels, B. (2007). Peroxisome proliferator-activated receptors mediate pleiotropic actions of statins. Circ. Res. 100, 1394-1395. doi: 10.1161/01.RES.0000269334.42814.d2

Petersen, R. C., Thomas, R. G., Grundman, M., Bennett, D., Doody, R., Ferris, S., et al. (2005). Vitamin E and donepezil for the treatment of mild cognitive impairment. N. Engl. J. Med. 352, 2379-2388. doi: 10.1056/NEJMoa050151

Pratico, D. (2008). Evidence of oxidative stress in Alzheimer's disease brain and antioxidant therapy: lights and shadows. Ann. N. Y. Acad. Sci. 1147, 70-78. doi: 10.1196/annals.1427.010

Raber, J., Wong, D., Yu, G. Q., Buttini, M., Mahley, R. W., Pitas, R. E., et al. (2000). Apolipoprotein E and cognitive performance. Nature 404, 352-354. doi: $10.1038 / 35006165$

Racchi, M., Baetta, R., Salvietti, N., Ianna, P., Franceschini, G., Paoletti, R., et al. (1997). Secretory processing of amyloid precursor protein is inhibited by increase in cellular cholesterol content. Biochem. J. 322(Pt 3), 893-898.

Rea, T. D., Breitner, J. C., Psaty, B. M., Fitzpatrick, A. L., Lopez, O. L., Newman, A. B., et al. (2005). Statin use and the risk of incident dementia: the cardiovascular health study. Arch. Neurol. 62, 1047-1051. doi: 10.1001/archneur.62.7.1047

Refolo, L. M., Malester, B., LaFrancois, J., Bryant-Thomas, T., Wang, R., Tint, G. S., etal. (2000). Hypercholesterolemia accelerates the Alzheimer's amyloid pathology in a transgenic mouse model. Neurobiol. Dis. 7, 321-331. doi: 10.1006/nbdi.2000.0304

Reiman, E. M., Chen, K., Liu, X., Bandy, D., Yu, M., Lee, W., et al. (2009). Fibrillar amyloid- $\beta$ burden in cognitively normal people at 3 levels of genetic risk for Alzheimer's disease. Proc. Natl. Acad. Sci. U.S.A. 106, 6820-6825. doi: 10.1073/pnas.0900345106

Reitz, C., Tang, M. X., Schupf, N., Manly, J. J., Mayeux, R., and Luchsinger, J. A. (2010). Association of higher levels of high-density lipoprotein cholesterol in elderly individuals and lower risk of late-onset Alzheimer disease. Arch. Neurol. 67, 1491-1497. doi: 10.1001/archneurol.2010.297

Riekse, R. G., Li, G., Petrie, E. C., Leverenz, J. B., Vavrek, D., Vuletic, S., et al. (2006). Effect of statins on Alzheimer's disease biomarkers in cerebrospinal fluid. J. Alzheimers Dis. 10, 399-406.

Rockwood, K., Kirkland, S., Hogan, D. B., MacKnight, C., Merry, H., Verreault, R., et al. (2002). Use of lipid-lowering agents, indication bias, and the risk of dementia in community-dwelling elderly people. Arch. Neurol. 59, 223-227. doi: 10.1001/archneur.59.2.223

Roensch, J., Crisby, M., Nordberg, A., Xiao, Y., Zhang, L. J., and Guan, Z. Z. (2007). Effects of statins on alpha7 nicotinic receptor, cholinesterase and alpha-form of secreted amyloid precursor peptide in SH-SY5Y cells. Neurochem. Int. 50, 800-806. doi: 10.1016/j.neuint.2007.02.001 
Roglans, N., Sanguino, E., Peris, C., Alegret, M., Vazquez, M., Adzet, T., et al. (2002). Atorvastatin treatment induced peroxisome proliferator-activated receptor alpha expression and decreased plasma nonesterified fatty acids and liver triglyceride in fructose-fed rats. J. Pharmacol. Exp. Ther. 302, 232-239. doi: 10.1124/jpet.302.1.232

Rojas-Fernandez, C. H., and Cameron, J. C. (2012). Is statin-associated cognitive impairment clinically relevant? A narrative review and clinical recommendations. Ann. Pharmacother. 46, 549-557. doi: 10.1345/aph.1Q620

Romas, S. N., Tang, M. X., Berglund, L., and Mayeux, R. (1999). APOE genotype, plasma lipids, lipoproteins, and AD in community elderly. Neurology 53, 517-521. doi: 10.1212/WNL.53.3.517

Sabbagh, M., Zahiri, H. R., Ceimo, J., Cooper, K., Gaul, W., Connor, D., et al. (2004). Is there a characteristic lipid profile in Alzheimer's disease? J. Alzheimers Dis. 6 , 585-589; discussion 673-681.

Sagare, A., Deane, R., Bell, R. D., Johnson, B., Hamm, K., Pendu, R., et al. (2007) Clearance of amyloid-beta by circulating lipoprotein receptors. Nat. Med. 13, 1029-1031. doi: 10.1038/nm1635

Sagare, A. P., Deane, R., Zetterberg, H., Wallin, A., Blennow, K., and Zlokovic, B. V. (2011). Impaired lipoprotein receptor-mediated peripheral binding of plasma amyloid-beta is an early biomarker for mild cognitive impairment preceding Alzheimer's disease. J. Alzheimers Dis. 24, 25-34. doi: 10.3233/JAD-2010-101248

Sano, M., Bell, K. L., Galasko, D., Galvin, J. E., Thomas, R. G., van Dyck, C. H., etal. (2011). A randomized, double-blind, placebo-controlled trial of simvastatin to treat Alzheimer disease. Neurology 77, 556-563. doi: 10.1212/WNL.0b013e318228bf11

Sano, M., Ernesto, C., Thomas, R. G., Klauber, M. R., Schafer, K., Grundman, M., et al. (1997). A controlled trial of selegiline, alpha-tocopherol, or both as treatment for Alzheimer's disease. The Alzheimer's Disease Cooperative Study N. Engl. J. Med. 336, 1216-1222. doi: 10.1056/NEJM199704243361704

Sattar, N., Preiss, D., Murray, H. M., Welsh, P., Buckley, B. M., de Craen, A. J., et al. (2010). Statins and risk of incident diabetes: a collaborative meta-analysis of randomised statin trials. Lancet 375, 735-742. doi: 10.1016/S0140-6736(09)61965-6

Schneider, A., Araujo, G. W., Trajkovic, K., Herrmann, M. M., Merkler, D., Mandelkow, E. M., et al. (2004). Hyperphosphorylation and aggregation of tau in experimental autoimmune encephalomyelitis. J. Biol. Chem. 279, 55833-55839. doi: 10.1074/jbc.M409954200

Schonknecht, P., Lutjohann, D., Pantel, J., Bardenheuer, H., Hartmann, T., von Bergmann, K., et al. (2002). Cerebrospinal fluid 24S-hydroxycholesterol is increased in patients with Alzheimer's disease compared to healthy controls. Neurosci. Lett. 324, 83-85. doi: 10.1016/S0304-3940(02)00164-7

Serrano-Pozo, A., Vega, G. L., Lutjohann, D., Locascio, J. J., Tennis, M. K., Deng, A., et al. (2010). Effects of simvastatin on cholesterol metabolism and Alzheimer disease biomarkers. Alzheimer Dis. Assoc. Disord. 24, 220-226. doi: 10.1097/WAD.0b013e3181d61fea

Sever, P. S., Dahlöf, B., Poulter, N. R., Wedel, H., Beevers, G., Caulfield, M., et al. (2003). Prevention of coronary and stroke events with atorvastatin in hypertensive patients who have average or lower-than-average cholesterol concentrations, in the Anglo-Scandinavian Cardiac Outcomes Trial - Lipid Lowering Arm (ASCOTLLA): a multicentre randomised controlled trial. Lancet 361, 1149-1158. doi: 10.1016/S0140-6736(03)12948-0

Shepardson, N. E., Shankar, G. M., and Selkoe, D. J. (2011). Cholesterol level and statin use in Alzheimer disease: II. Review of human trials and recommendations. Arch. Neurol. 68, 1385-1392. doi: 10.1001/archneurol.2011.242

Shepherd, J., Blauw, G. J., Murphy, M. B., Bollen, E. L., Buckley, B. M., Cobbe, S. M., et al. (2002). Pravastatin in elderly individuals at risk of vascular disease (PROSPER): a randomised controlled trial. Lancet 360, 1623-1630. doi 10.1016/S0140-6736(02)11600-X

Shepherd, J., Cobbe, S. M., Ford, I., Isles, C. G., Lorimer, A. R., MacFarlane, P. W., et al. (1995). Prevention of coronary heart disease with pravastatin in men with hypercholesterolemia. West of Scotland Coronary Prevention Study Group. N. Engl. J. Med. 333, 1301-1307. doi: 10.1056/NEJM1995111633 32001

Shie, F. S., Jin, L. W., Cook, D. G., Leverenz, J. B., and LeBoeuf, R. C. (2002). Diet-induced hypercholesterolemia enhances brain A beta accumulation in transgenic mice. Neuroreport 13, 455-459. doi: 10.1097/00001756-20020325000019

Shinohara, M., Sato, N., Kurinami, H., Takeuchi, D., Takeda, S., Shimamura, M., et al. (2010). Reduction of brain beta-amyloid (Abeta) by fluvastatin, a hydroxymethylglutaryl-CoA reductase inhibitor, through increase in degradation of amyloid precursor protein C-terminal fragments (APP-CTFs) and Abeta clearance. J. Biol. Chem. 285, 22091-22102. doi: 10.1074/jbc.M110. 102277

Simons, M., Keller, P., De Strooper, B., Beyreuther, K., Dotti, C. G., and Simons, K. (1998). Cholesterol depletion inhibits the generation of beta-amyloid in hippocampal neurons. Proc. Natl. Acad. Sci. U.S.A. 95, 6460-6464. doi: 10.1073/pnas.95.11.6460

Simons, M., Schwarzler, F., Lutjohann, D., von Bergmann, K., Beyreuther, K., Dichgans, J., et al. (2002). Treatment with simvastatin in normocholesterolemic patients with Alzheimer's disease: a 26-week randomized, placebo-controlled, double-blind trial. Ann. Neurol. 52, 346-350. doi: 10.1002/ana.10292

Sjogren, M., Gustafsson, K., Syversen, S., Olsson, A., Edman, A., Davidsson, P., et al. (2003). Treatment with simvastatin in patients with Alzheimer's disease lowers both alpha- and beta-cleaved amyloid precursor protein. Dement. Geriatr. Cogn. Disord. 16, 25-30. doi: 10.1159/000069989

Skoog, I., Lernfelt, B., Landahl, S., Palmertz, B., Andreasson, L. A., Nilsson, L., et al. (1996). 15-year longitudinal study of blood pressure and dementia. Lancet 347, 1141-1145. doi: 10.1016/S0140-6736(96)90608-X

Small, G. W., Siddarth, P., Silverman, D. H., Ercoli, L. M., Miller, K. J., Lavretsky, H., et al. (2008). Cognitive and cerebral metabolic effects of celecoxib versus placebo in people with age-related memory loss: randomized controlled study. Am. J. Geriatr. Psychiatry 16, 999-1009. doi: 10.1097/JGP.0b013e31818cd3a4

Small, S. A., and Duff, K. (2008). Linking A beta and tau in late-onset Alzheimer's disease: a dual pathway hypothesis. Neuron 60, 534-542. doi: 10.1016/j.neuron.2008.11.007

Sparks, D. L. (1997). Coronary artery disease, hypertension, ApoE, and cholesterol: a link to Alzheimer's disease? Ann. N. Y. Acad. Sci. 826, 128-146. doi: 10.1111/j.1749-6632.1997.tb48466.x

Sparks, D. L., Kryscio, R. J., Sabbagh, M. N., Connor, D. J., Sparks, L. M., and Liebsack, C. (2008). Reduced risk of incident AD with elective statin use in a clinical trial cohort. Curr. Alzheimer Res. 5, 416-421. doi: 10.2174/156720508785132316

Strazzullo, P., Kerry, S. M., Barbato, A., Versiero, M., D'Elia, L., and Cappuccio, F. P. (2007). Do statins reduce blood pressure?: a metaanalysis of randomized, controlled trials. Hypertension 49, 792-798. doi: 10.1161/01.HYP.0000259737.43916.42

Suzuki, S., Numakawa, T., Shimazu, K., Koshimizu, H., Hara, T., Hatanaka, H., et al. (2004). BDNF-induced recruitment of TrkB receptor into neuronal lipid rafts: roles in synaptic modulation. J. Cell Biol. 167, 1205-1215. doi: $10.1083 /$ jcb. 200404106

Svennerholm, L., and Gottfries, C. G. (1994). Membrane lipids, selectively diminished in Alzheimer brains, suggest synapse loss as a primary event in early-onset form (type I) and demyelination in late-onset form (type II). J. Neurochem. 62, 1039-1047. doi: 10.1046/j.1471-4159.1994.62031039.x

Takeda, S., Sato, N., Rakugi, H., and Morishita, R. (2011). Molecular mechanisms linking diabetes mellitus and Alzheimer disease: beta-amyloid peptide, insulin signaling, and neuronal function. Mol. Biosyst. 7, 1822-1827. doi: 10.1039/c0mb00302f

Tamboli, I., Barth, E., Christian, L., Siepmann, M., Kumar, S., Singh, S., et al. (2010). Statins promote the degradation of extracellular amyloid \{beta\}-peptide by microglia via stimulation of exosome-associated insulin-degrading enzyme (IDE) secretion. J. Biol. Chem. 285, 37405-37414. doi: 10.1074/jbc.M110. 149468

Tan, Z. S., Seshadri, S., Beiser, A., Wilson, P. W. F., Kiel, D. P., Tocco, M., et al. (2003). Plasma total cholesterol level as a risk factor for Alzheimer disease: the Framingham Study. Arch. Intern. Med. 163, 1053-1057. doi: 10.1001/archinte.163.9.1053

Tanaka, N., Abe-Dohmae, S., Iwamoto, N., Fitzgerald, M. L., and Yokoyama, S. (2011a). HMG-CoA reductase inhibitors enhance phagocytosis by upregulating ATP-binding cassette transporter A7. Atherosclerosis 217, 407-414. doi: 10.1016/j.atherosclerosis.2011.06.031

Tanaka, N., Abe-Dohmae, S., Iwamoto, N., and Yokoyama, S. (2011b). Roles of ATP-binding cassette transporter A7 in cholesterol homeostasis and host defense system. J. Atheroscler. Thromb. 18, 274-281. doi: 10.5551/jat.6726

Teunissen, C. E., Lütjohann, D., von Bergmann, K., Verhey, F., Vreeling, F., Wauters, A., etal. (2003). Combination of serum markers related to several mechanisms in Alzheimer's disease. Neurobiol. Aging 24, 893-902. doi: $10.1016 /$ S0197-4580(03)00005-8 
Thal, D. R., Griffin, W. S., de Vos, R. A., and Ghebremedhin, E. (2008). Cerebral amyloid angiopathy and its relationship to Alzheimer's disease. Acta Neuropathol. 115, 599-609. doi: 10.1007/s00401-008-0366-2

Thal, L. J., Ferris, S. H., Kirby, L., Block, G. A., Lines, C. R., Yuen, E., etal. (2005). A randomized, double-blind, study of rofecoxib in patients with mild cognitive impairment. Neuropsychopharmacology 30, 1204-1215. doi: 10.1038/sj.npp.1300690

Tong, X.-K., Lecrux, C., and Hamel, E. (2012). Age-dependent rescue by simvastatin of Alzheimer's disease cerebrovascular and memory deficits. J. Neurosci. 32, 47054715. doi: 10.1523/JNEUROSCI.0169-12.2012

Tong, X. K., Nicolakakis, N., Fernandes, P., Ongali, B., Brouillette, J., Quirion, R. et al. (2009). Simvastatin improves cerebrovascular function and counters soluble amyloid-beta, inflammation and oxidative stress in aged APP mice. Neurobiol. Dis. 35, 406-414. doi: 10.1016/j.nbd.2009.06.003

Trachtenberg, A. J., Filippini, N., Cheeseman, J., Duff, E. P., Neville, M. J., Ebmeier, K. P., et al. (2012). The effects of APOE on brain activity do not simply reflect the risk of Alzheimer's disease. Neurobiol. Aging 33, 618.e1-618.e13. doi 10.1016/j.neurobiolaging.2010.11.011

Vance, J. E., Karten, B., and Hayashi, H. (2006). Lipid dynamics in neurons. Biochem Soc. Trans. 34(Pt 3), 399-403.

Vega, G. L., Weiner, M. F., Lipton, A. M., von Bergmann, K., Lutjohann, D., Moore, C., et al. (2003). Reduction in levels of 24S-hydroxycholesterol by statin treatment in patients with Alzheimer disease. Arch. Neurol. 60, 510-515. doi: 10.1001/archneur.60.4.510

Verghese, P. B., Castellano, J. M., and Holtzman, D. M. (2011). Apolipoprotein E in Alzheimer's disease and other neurological disorders. Lancet Neurol. 10, 241-252. doi: 10.1016/S1474-4422(10)70325-2

Wagstaff, L. R., Mitton, M. W., Arvik, B. M., and Doraiswamy, P. M. (2003). Statinassociated memory loss: analysis of 60 case reports and review of the literature. Pharmacotherapy 23, 871-880. doi: 10.1592/phco.23.7.871.32720

Wahrle, S., Das, P., Nyborg, A. C., McLendon, C., Shoji, M., Kawarabayashi, T., et al. (2002). Cholesterol-dependent gamma-secretase activity in buoyant cholesterol-rich membrane microdomains. Neurobiol. Dis. 9, 11-23. doi: 10.1006/nbdi.2001.0470

Watts, G. F., Chan, D. C., Barrett, P. H., O’Neill, F. H., and Thompson, G. R. (2003). Effect of a statin on hepatic apolipoprotein B-100 secretion and plasma campesterol levels in the metabolic syndrome. Int. J. Obes. Relat. Metab. Disord. 27, 862-865. doi: 10.1038/sj.ijo.0802287

Weiner, M. W., Veitch, D. P., Aisen, P. S., Beckett, L. A., Cairns, N. J. Green, R. C., et al. (2013). The Alzheimer's Disease Neuroimaging Initiative: a review of papers published since its inception. Alzheimers Dement. 9, 7. doi: 10.1016/j.jalz.2013.05.1769

Weller, R. O., Boche, D., and Nicoll, J. A. (2009). Microvasculature changes and cerebral amyloid angiopathy in Alzheimer's disease and their potential impact on therapy. Acta Neuropathol. 118, 87-102. doi: 10.1007/s00401-009-0498-z

Weverling-Rijnsburger, A. W., Blauw, G. J., Lagaay, A. M., Knook, D. L., Meinders, A. E., and Westendorp, R. G. (1997). Total cholesterol and risk of mortality in the oldest old. Lancet 350, 1119-1123. doi: 10.1016/S0140-6736(97)04430-9

White, H. D., Simes, R. J., Anderson, N. E., Hankey, G. J., Watson, J. D., Hunt, D., et al. (2000). Pravastatin therapy and the risk of stroke. N. Engl. J. Med. 343, 317-326. doi: 10.1056/NEJM200008033430502

Wisdom, N. M., Callahan, J. L., and Hawkins, K. A. (2011). The effects of apolipoprotein $\mathrm{E}$ on non-impaired cognitive functioning: a meta-analysis. Neurobiol. Aging 32, 63-74. doi: 10.1016/j.neurobiolaging.2009.02.003

Wolozin, B., Kellman, W., Ruosseau, P., Celesia, G. G., and Siegel, G. (2000). Decreased prevalence of Alzheimer disease associated with 3-hydroxy3-methyglutaryl coenzyme A reductase inhibitors. Arch. Neurol. 57, 1439-1443. doi: 10.1001/archneur.57.10.1439
Won, J. S., Im, Y. B., Khan, M., Contreras, M., Singh, A. K., and Singh, I. (2008). Lovastatin inhibits amyloid precursor protein (APP) beta-cleavage through reduction of APP distribution in Lubrol WX extractable low density lipid rafts. J. Neurochem. 105, 1536-1549. doi: 10.1111/j.1471-4159.2008.05283.x Wong, W. B., Lin, V. W., Boudreau, D., and Devine, E. B. (2013). Statins in the prevention of dementia and Alzheimer's disease: a meta-analysis of observational studies and an assessment of confounding. Pharmacoepidemiol. Drug Saf. 22, 345-358. doi: 10.1002/pds.3381

Wyss-Coray, T. (2006). Inflammation in Alzheimer disease: driving force, bystander or beneficial response? Nat. Med. 12, 1005-1015.

Xiao, Q., Gil, S. C., Yan, P., Wang, Y., Han, S., Gonzales, E., et al. (2012). Role of phosphatidylinositol clathrin assembly lymphoid-myeloid leukemia (PICALM) in intracellular amyloid precursor protein (APP) processing and amyloid plaque pathogenesis. J. Biol. Chem. 287, 21279-21289. doi: 10.1074/jbc.M111.338376

Yarchoan, M., Xie, S. X., Kling, M. A., Toledo, J. B., Wolk, D. A., Lee, E. B., etal. (2012). Cerebrovascular atherosclerosis correlates with Alzheimer pathology in neurodegenerative dementias. Brain 135(Pt 12), 3749-3756. doi: 10.1093/brain/aws271

Yoshitake, T., Kiyohara, Y., Kato, I., Ohmura, T., Iwamoto, H., Nakayama, K., et al. (1995). Incidence and risk factors of vascular dementia and Alzheimer's disease in a defined elderly Japanese population: the Hisayama Study. Neurology 45, 1161-1168. doi: 10.1212/WNL.45.6.1161

Yu, J. T., and Tan, L. (2012). The role of clusterin in Alzheimer's disease: pathways, pathogenesis, and therapy. Mol. Neurobiol. 45, 314-326. doi: 10.1007/s12035012-8237-1

Zamrini, E., McGwin, G., and Roseman, J. M. (2004). Association between statin use and Alzheimer's disease. Neuroepidemiology 23, 94-98. doi: 10.1159/000073981

Zandi, P. P., Sparks, D. L., Khachaturian, A. S., Tschanz, J., Norton, M., Steinberg, M., et al. (2005). Do statins reduce risk of incident dementia and Alzheimer disease? The Cache County Study. Arch. Gen. Psychiatry 62, 217-224. doi: 10.1001/archpsyc.62.2.217

Zhou, Q., and Liao, J. K. (2010). Pleiotropic effects of statins: basic research and clinical perspectives. Circ. J. 74, 818-826. doi: 10.1253/circj.CJ-10-0110

Zhou, Y., Suram, A., Venugopal, C., Prakasam, A., Lin, S., Su, Y., et al. (2008). Geranylgeranyl pyrophosphate stimulates gamma-secretase to increase the generation of Abeta and APP-CTFgamma. FASEB J. 22, 47-54. doi: 10.1096/fj.07-8175com

Zhu, X., Lee, H.-G., Perry, G., and Smith, M. A. (2007). Alzheimer disease, the two-hit hypothesis: an update. Biochim. Biophys. Acta 1772, 494-502. doi: 10.1016/j.bbadis.2006.10.014

Conflict of Interest Statement: The authors declare that the research was conducted in the absence of any commercial or financial relationships that could be construed as a potential conflict of interest.

Received: 25 January 2014; accepted: 30 March 2014; published online: 23 April 2014 Citation: Shinohara M, Sato N, Shimamura M, Kurinami H, Hamasaki T, Chatterjee A, Rakugi H and Morishita R (2014) Possible modification of Alzheimer's disease by statins in midlife: interactions with genetic and non-genetic risk factors. Front. Aging Neurosci. 6:71. doi: 10.3389/fnagi.2014.00071

This article was submitted to the journal Frontiers in Aging Neuroscience.

Copyright (c) 2014 Shinohara, Sato, Shimamura, Kurinami, Hamasaki, Chatterjee, Rakugi and Morishita. This is an open-access article distributed under the terms of the Creative Commons Attribution License (CC BY). The use, distribution or reproduction in other forums is permitted, provided the original author(s) or licensor are credited and that the original publication in this journal is cited, in accordance with accepted academic practice. No use, distribution or reproduction is permitted which does not comply with these terms. 